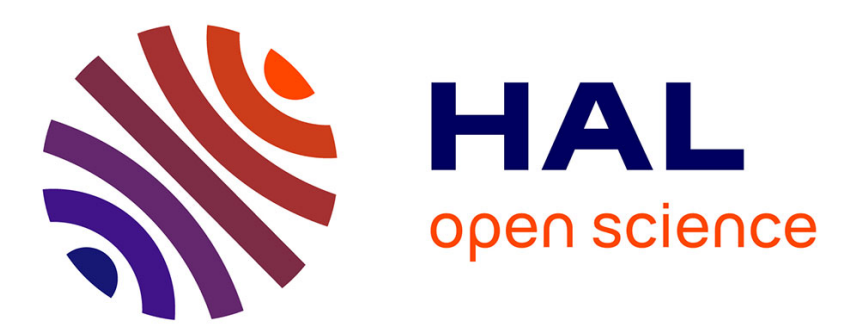

\title{
Impact of synkinematic sedimentation on the geometry and dynamics of compressive growth structures: Insights from analogue modelling
}

\author{
Laurie Barrier, Thierry Nalpas, Denis Gapais, Jean-Noël Proust
}

\section{- To cite this version:}

Laurie Barrier, Thierry Nalpas, Denis Gapais, Jean-Noël Proust. Impact of synkinematic sedimentation on the geometry and dynamics of compressive growth structures: Insights from analogue modelling. Tectonophysics, 2013, 608, pp.737-752. 10.1016/j.tecto.2013.08.005 . insu-00917662

\section{HAL Id: insu-00917662 \\ https://hal-insu.archives-ouvertes.fr/insu-00917662}

Submitted on 22 Jan 2014

HAL is a multi-disciplinary open access archive for the deposit and dissemination of scientific research documents, whether they are published or not. The documents may come from teaching and research institutions in France or abroad, or from public or private research centers.
L'archive ouverte pluridisciplinaire HAL, est destinée au dépôt et à la diffusion de documents scientifiques de niveau recherche, publiés ou non, émanant des établissements d'enseignement et de recherche français ou étrangers, des laboratoires publics ou privés. 
Impact of synkinematic sedimentation on the geometry and dynamics of compressive growth structures: insights from analogue modelling

Laurie BARRIER $^{\mathrm{a}, \mathrm{b}}$, Thierry NALPAS ${ }^{\mathrm{a}}$, Denis GAPAIS ${ }^{\mathrm{a}}$, and Jean-Noël PROUST ${ }^{\mathrm{a}}$

${ }^{a}$ Géosciences Rennes, Université de Rennes 1, UMR 6118 CNRS, Campus de Beaulieu, 35042 Rennes Cedex, France.

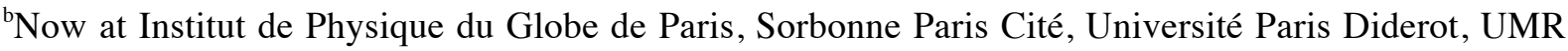
7154 CNRS, 1 rue Jussieu, F-75005 Paris, France.

E-mail address of the corresponding author: barrier@ipgp.fr

\begin{abstract}
Analogue sandbox models have been set up to study the impact of synkinematic deposits on the geometry and evolution of single thrusts and folds according to different sedimentation modes (a slow or rapid sedimentation rate that is constant or changing in space and time) and rheological profiles (thin or thick sedimentary series, with or without a basal décollement level). A first series of experiments documents the influence of synkinematic deposits according to their sedimentation rate and the rheology of the prekinematic materials. A second series investigates the influence of changes in the sedimentation rate through time. A third one considers the influence of changes in the sedimentation rate in space. All these experiments suggest that the geometry and evolution of single compressive growth structures vary according to the sedimentation rate. The number and dip of their frontal thrust segments change with the ratio $\mathrm{R}$ between the sedimentation rate at the footwall of the
\end{abstract}


faults and the uplift rate of their hanging wall. The latter is then more or less uplifted depending on the dip of the thrusts. As a result, the overall structure has either a fault-bend fold or a fault-propagation fold geometry. These rules are verified when the ratio $\mathrm{R}$ changes in space or through time. In addition, the rheological profile of the models also affects the geometry and evolution of compressive growth structures. Their structural style, as well as the synsedimentary splitting and steepening of the associated thrusts, varies according to the occurrence and strength of the brittle and ductile layers. According to this modelling study, the ratio $\mathrm{R}$ and its changes in space and time, along with the rheology of the deformed materials, are key parameters to better understand the geometrical and kinematical complexities of natural growth thrusts and folds and to improve their interpretation.

Keywords: analogue modelling, thrust, synkinematic sedimentation, compressive growth structure, décollement level.

\section{Introduction}

Based on fieldwork, experimental or numerical models, and theoretical studies, it has been demonstrated that erosion and sedimentation impact the geometry and kinematics of compressive systems (e.g., Koons, 1990; Willett et al., 1993; Beaumont et al., 1994; DeCelles and Mitra, 1995; Avouac and Burov, 1996; Meigs and Burbank, 1997; Mugnier et al., 1997; Willett, 1999; Storti et al., 2000; Barrier et al., 2002; Hilley et al., 2004; McClay and Whitehouse, 2004; Whipple and Meade, 2006; Konstantinovskaia and Malavieille, 2005, 2011; Stockmal et al., 2007; Duerto and McClay, 2009; Whipple, 2009; Malavieille, 2010; Graveleau et al., 2012). In particular, many studies have shown that deformation of thrust wedges and compressive basins changes according to the magnitude of these surface processes (e.g., King et al., 1988; Storti and McClay, 1995; Hardy et al., 1998; Braun and Pauselli, 2004; Simpson, 2006; Bonnet et al., 2007, 2008; Wu and McClay, 2011; Fillon et al., 2013). When submitted to low erosion or sedimentation rates, fold-and-thrust belts exhibit widely 
spaced thrusts that develop in sequence toward the foreland. In contrast, when submitted to high erosion or sedimentation rates, these belts show tightly spaced thrusts, which activate out of sequence toward the foreland or the hinterland alternately. High sedimentation rates also promote the subsidence of compressive basins and prolong the activity of their bordering faults. Hence, it appears that synkinematic erosion and sedimentation influence the location, activity and sequences of thrusts within compressive belts. However, previous works on thrust wedges have not clearly investigated the effect of surface processes at the scale of the elementary structures that composed these systems.

Only a few studies have addressed the impact of erosion and sedimentation on single growth thrusts and folds. They demonstrate that erosion facilitates and prolongs the activity of thrusts without changing their geometry (Raleigh and Griggs, 1963; Elliott, 1976; Johnson, 1981; Price and Johnson, 1982; Willemin, 1984; Merle and Abidi, 1995). They also highlight that sedimentation affects the geometry and dynamics of thrusts and folds (Tondji-Biyo, 1995; Nalpas et al.; 1999; Casas et al., 2001; Barrier et al., 2002; Nalpas et al.; 2003; Gestain et al., 2004; Strayer et al., 2004; Pichot and Nalpas, 2009; Vidal-Royo et al., 2011). However, the influence of synkinematic deposits on compressive growth structures has not yet been systematically explored according to the different sedimentation modes (a slow or rapid sedimentation rate that is constant or changing in space and time) that can occur in natural systems. Moreover, this influence is usually studied by considering only one rheological layering of the prekinematic terrains, whereas these structures can develop within various stratigraphic stacks (thin or thick, with or without a basal décollement level).

In this article, we present three series of brittle and brittle-ductile analogue models designed to further document the effect of synkinematic sedimentation on the geometry and evolution of single thrusts and the associated folds. The first series of experiments investigates the influence of synkinematic deposits according to their sedimentation rate and the rheology of the prekinematic materials. The second series focuses on the influence of changes in the sedimentation rate through time. The third one considers the influence of changes in the sedimentation rate in space. Herein, we describe the experimental technique, present the results of the models and discuss these results. Our experiments show how synkinematic deposits, along with the rheology of the deformed layers, can impact the structure and kinematics of the growth thrust and folds depending on the sedimentation rate 
and its changes in space and time. Consequently, many geometrical and kinematical complexities of natural compressive growth structures can be explained.

\section{Experimental methodology}

The physical models presented below are replicas of natural examples scaled-down in terms of dimensions, rheology, and boundary conditions. The experimental procedure is similar to the one frequently used to model compressive systems with brittle and brittle-ductile rheologies (e.g., Malavieille, 1984; Ballard et al., 1987; Liu et al., 1992; Storti and McClay, 1995; Cotton and Koyi, 2000; Nalpas et al., 2003; Smit et al., 2003; Graveleau et al., 2012 and references therein). A geometric and dynamic similarity between the experiments and nature is obtained by keeping the average strength of the ductile layers correctly scaled with respect to the strength of the brittle layers and the gravity forces (e.g., Hubbert, 1937; Ramberg, 1981; Davy and Cobbold, 1991; Weijermars et al., 1993).

In this study, the models were designed to represent sedimentary covers a few kilometres thick that deform with a shortening rate of a few millimetres per year to reach a total shortening of a few kilometres. In practice, given the physical properties of the materials used, these experiments must fulfil two main conditions to be properly scaled (e.g., Bonini, 2001; Brun, 2002; Costa and Vendeville, 2002). First, the ratios of the lengths and stresses between the models and their natural prototypes must be nearly equal. Second, the models must deform a few billion times faster than nature, which is archived for a shortening velocity of a few centimetres per hour. The corresponding geometric and dynamic scaling of the experiments is presented in Table 1. In this table, (1) the length ratio between the models and nature is fixed by the experimenter, (2) the density and viscosity ratios are fixed by the rheology of the analogue materials, and (3) the shortening rate, time and stress ratios are imposed by the ones in (1) and (2). The models to nature ratios, chosen or fixed from scaling laws (see Hubbert, 1937; Ramberg, 1981; Davy and Cobbold, 1991; Weijermars et al., 1993), are thus $10^{-5}$ for length (1 $\mathrm{cm}$ in the models represents $1 \mathrm{~km}$ in nature), $10^{-10}$ for time ( $2 \mathrm{~h}$ represents approximately $\left.1.5 \mathrm{My}\right)$ and $10^{-5}$ for stresses (the models are nearly $10^{5}$ times weaker than their natural prototypes). 
In these experiments, dry Fontainebleau quartz sand is used to model the brittle (i.e. frictional) behaviour of sedimentary rocks with Mohr-Coulomb properties. This sand has a mean grain size of approximately $250 \mu \mathrm{m}$, an internal friction angle close to $30-35^{\circ}$, a negligible cohesion, and a mean density of approximately $1,400 \mathrm{~kg} / \mathrm{m}^{3}$. Silicone putty (Rhodorsil Gomme GS1 RG 70,009 manufactured by Rhône-Poulenc, France) is used to model the ductile (i.e. viscous) behaviour of weak sedimentary rocks such as shales, clays, marls, or evaporites. When submitted to deformation velocities of a few centimetres per hour, this silicone putty is a quasi-newtonian fluid with a mean viscosity close to $10^{4} \mathrm{~Pa} . \mathrm{s}$ at $20^{\circ} \mathrm{C}$ and a mean density of approximately $1,300 \mathrm{~kg} / \mathrm{m}^{3}$. Piling up sand and silicone layers provides analogue models with strength profiles homothetic to those of natural sedimentary series (e.g., Faugère and Brun, 1984; Davy and Cobbold, 1991; Weijermars et al., 1993). Before compression, the models were a few centimetres thick and were made up of a white and black sand pile either lying or not on a silicone layer (Fig. 1). In these stacks, the silicone layer represents a potential décollement level at the applied strain rate, whereas the overlying sand represents a brittle prekinematic cover. In this brittle cover, the sand layers of different colours have the same rheological behaviour.

The experimental models were set in an apparatus that comprises a box wide enough $(55 \times 60$ $\mathrm{cm}$ ) to permit large deformations without boundary effects. This box had two opposing walls: one attached on a fixed bottom and one stuck on a rigid mobile basal plate that could slide over the fixed bottom (Fig. 1). The two other sides were free in order to avoid sideways frictions and ensure uniform compressive stresses. To transmit horizontal displacements within the box, the mobile wall and the basal plate were pushed inward at a constant velocity by a screwjack. At the base of the models, the free moving edge of the mobile basal plate induces a linear velocity discontinuity (VD) that forces deformation localization (e.g., Malavieille, 1984; Ballard et al., 1987; Allemand et al., 1989). According to the scaling requirements, a constant deformation velocity of $2.5 \mathrm{~cm} / \mathrm{h}^{1}$ was used to reach a total shortening of $5 \mathrm{~cm}$ for all experiments. During shortening, fresh white and blue sand was sprinkled manually onto the models to mimic synkinematic sedimentation. Using this technique, synkinematic deposits can be evenly distributed or localized along strike with a constant or changing rate through time (e.g., Tondji-Biyo, 1995; Nalpas et al.; 1999; Barrier et al., 2002; Nalpas et al.; 
2003; Gestain et al., 2004; Pichot and Nalpas, 2009), in order to reproduce a spectrum of sedimentation modes that can occur in compressive systems.

In the three series of experiments presented below, the sedimentation rate was chosen relative to the uplift rate of the growth structures that developed during shortening. The different models can thus be compared using a non-dimensional parameter $\mathrm{R}$ that corresponds to a ratio between two velocities: the sedimentation rate at the footwall of the main fault zone of each model $\left(\mathrm{V}_{\text {sed }}\right)$ and the uplift rate of its hanging wall $\left(\mathrm{V}_{\text {upl }}\right)$ (see also Storti and Salvini, 1996; Barrier et al., 2002; Pichot and Nalpas, 2009). In the first series of experiments, models were uniformly covered by synkinematic sand deposited with a constant sedimentation rate during the entire shortening period. In these models, the ratio $\mathrm{R}\left(\mathrm{V}_{\text {sed }} / \mathrm{V}_{\text {upl }}\right)$ was set to $0\left(\mathrm{~V}_{\text {sed }}=0\right), 1 / 2\left(\mathrm{~V}_{\text {sed }}<\mathrm{V}_{\text {up }}\right), 1\left(\mathrm{~V}_{\text {sed }}=\mathrm{V}_{\text {upl }}\right), 2$ or higher $\left(\mathrm{V}_{\text {sed }}>\mathrm{V}_{\text {upl }}\right)$, in order to simulate the development of a growth structure above or below a sedimentation base level. However, changes in $\mathrm{R}$ in space and time also classically occur during the development of natural growth-structures (e.g., Riba, 1976; Burbank and Vergés, 1994; Williams et al., 1998; Arenas et al., 2001). Therefore, in the second series, models were also uniformly covered by synkinematic sand with a changing sedimentation rate through time. In these models, the ratio $\mathrm{R}$ is alternately lower or higher than $1\left(\mathrm{~V}_{\text {sed }}<\mathrm{V}_{\text {upl }}\right.$ or $\left.\mathrm{V}_{\text {sed }}>\mathrm{V}_{\text {upl }}\right)$ over time. Finally, in the third series, models were covered by synkinematic sand deposited with a constant sedimentation rate during the entire shortening period, but non-uniformly in space. In these experiments, the ratio $\mathrm{R}$ varies between $0\left(\mathrm{~V}_{\text {sed }}=0\right)$ and $1\left(\mathrm{~V}_{\text {sed }}=\right.$ $\mathrm{V}_{\text {upl }}$ ) from place to place.

During deformation and sedimentation, photographs of the model surface were taken at regular time intervals to document the structure development in map view. After deformation, the structures were also observed through the models on a series of cross-sections perpendicular to the VD (i.e. parallel to the compression direction). In these cross-sections, deformation can be viewed using the coloured sand layers.

\section{Models with a constant sedimentation rate in space and time}


The first series of experiments consists of 41 models designed to test the influence of synkinematic deposits on compressive growth structures according to the sedimentation rate and the rheology of the prekinematic materials. In natural compressive systems, structures can develop within sedimentary series of different thicknesses lying above thin or thick décollement levels. To consider these different situations, three groups of experiments with different kinds of prekinematic rheological profiles are presented: (1) fully brittle models with different sand thicknesses (Tb=1,2 or $3 \mathrm{~cm}),(2)$ brittle-ductile models with the same silicone thickness at the base $(\mathrm{Td}=1 \mathrm{~cm})$ and different sand thicknesses above $(\mathrm{Tb}=1,2$ or $3 \mathrm{~cm})$, and (3) brittle-ductile models with different silicone thicknesses at the base $(\mathrm{Td}=1,2$ or $3 \mathrm{~cm})$ and the same sand thickness above $(\mathrm{Tb}=2 \mathrm{~cm})$. Independently from these rheological variations, all of these models were uniformly covered by synkinematic sand deposited with a constant sedimentation rate during the entire shortening period. However, this constant sedimentation rate is not the same from one model to another since the ratio $\mathrm{R}\left(\mathrm{V}_{\text {sed }} / \mathrm{V}_{\text {upl }}\right)$ was set to be $0\left(\mathrm{~V}_{\text {sed }}=0\right), 1 / 2\left(\mathrm{~V}_{\text {sed }}<\mathrm{V}_{\text {upl }}\right), 1\left(\mathrm{~V}_{\text {sed }}=\mathrm{V}_{\text {upl }}\right), 2$ or higher $\left(\mathrm{V}_{\text {sed }}>\mathrm{V}_{\text {up }}\right)$ for each prekinematic rheology (see Table 2 for the model parameters).

In most of the experiments in this first series, two thrust zones accommodate the shortening (Fig. 2). On the model surface, they can be identified by straight scarps bounding a topographic high that is covered or not by synkinematic deposits according to their sedimentation rate (Fig. 2A). In the cross-sections, these two scarps correspond to a main and a secondary conjugate thrust zone (Fig. 2B, $\mathrm{C}$ and $\mathrm{D})$. The main thrust zone roots on the VD with an offset antithetic to the motion of the mobile wall. Through this thrust zone, the fixed compartment of the models climbs over the mobile one. The hanging-wall deformation is then usually accommodated by the secondary thrust zone that developed with an offset synthetic to the motion of the mobile wall. In this situation, the hanging wall between the two conjugate thrust zones is uplifted in a pop-up structure. Besides these common geometrical features, the structure and evolution of the models vary according to their synkinematic sedimentation rate and prekinematic rheology.

\section{Brittle models with different sand thicknesses}


In a first group of experiments, the models are fully brittle and initially made up of a 1, 2 or 3 cm-thick prekinematic sand layer (Figs. 3 and 4). In these models, the main thrust zone is a single and permanent fault zone, whereas the secondary one is composed of several short-lived backthrusts (see other examples in Malavielle, 1984; Tondji-Biyo, 1995). These faults form one by one, rooted on the VD, before being passively carried upwards because of the motion of the main thrust zone. Then, they become inactive while the next one appears. The deformation is thus characterized by translations along faults and minor rotations between them without layer bending. However, from one model to another, the deformation pattern varies according to the prekinematic sand thickness and the synkinematic sedimentation rate.

In these purely brittle experiments, the number of secondary thrusts decreases when the prekinematic sand thickness increases (Fig. 3, models 1, 2 and 3). It also decreases when the synkinematic sedimentation rate increases (Figs. 3 and 4 , models a, b, c, d and e). When these secondary thrusts are fewer, their motion lasts longer and their individual offset is greater compared with the one of the permanent main fault zone. As a consequence, the symmetry of the deformation pattern in the brittle models increases with their total sand thickness.

Additionally, in experiments without synkinematic sedimentation $(\mathrm{R}=0)$ (Fig. 3, models 1a, $2 a$ and $3 a$ ), the main thrust zone is thin and convex upwards. It can be interpreted as a single and permanent thrust with a ramp-and-flat geometry. Its dip is approximately $30-35^{\circ}$ at the base, whereas it is close to $0^{\circ}$ at the surface (Fig. 5A). Above this upper flat, the hanging wall of the main thrust is curved on the underthrust compartment. Moreover, the horizontal offset of the main thrust is large compared with the one of the secondary faults. As a result, the overall structure mimics a fault-bend fold.

In experiments with a sedimentation rate lower than the hanging-wall uplift rate $(\mathrm{R} \sim 1 / 2)$ (Fig. 3, models 1b, 2b and 3b), the overall deformation resembles the one observed in the models without sedimentation $(\mathrm{R}=0)$. However, the upper part of the main thrust zone is steeper and its surface dip ranges between 10 and $30^{\circ}$ (Fig. 5A). Consequently, the horizontal offset of this thrust zone decreases while its vertical offset increases, thus amplifying the uplift of its hanging wall (Fig. 5B). When the prekinematic sand layer is thick (Fig. 3, models $2 \mathrm{~b}$ and $3 \mathrm{~b}$ ), the main thrust zone is also 
wider than in the case where $\mathrm{R}=0$. Accordingly, it is interpreted as either a broad single fault or several thrust segments. In any case, the synkinematic layers lying in the footwall of this fault zone are not deformed. In contrast, the growth strata deposited on its hanging wall are offset by the secondary thrusts and display offlap terminations.

In experiments with a sedimentation rate close to the hanging-wall uplift rate $(\mathrm{R} \sim 1)$ (Fig. 3, models $1 \mathrm{c}, 2 \mathrm{c}$ and $3 \mathrm{c}$ ), the main thrust zone is concave upwards with a very steep upper part. Its surface dip reaches $50^{\circ}$ and the uplift of its hanging wall increases accordingly (Fig. 5). When the prekinematic sand layer is thin (Fig. 3, model 1c), this main fault zone is narrow and corresponds to a permanent thrust. When the prekinematic sand layer is thick (Fig. 3, models $2 \mathrm{c}$ and $3 \mathrm{c}$ ), the main fault zone is broader and widens upwards. Surprisingly, it does not continue into the synkinematic deposits, which are made up of the same material as the prekinematic sand layer. With a triangular shape that is up against the synkinematic sediments, the main thrust zone cannot be interpreted as a single fault. Instead, it corresponds to a series of several temporary thrusts that developed in break-back sequence with an increasing dip at each depositional increment. At the footwall of this fault zone, the synkinematic layers that progressively seal the first thrusts are flat-lying or slightly overturned. On the hanging wall, the growth strata are offset by the secondary thrusts and display onlap and offlap terminations.

In experiments with a sedimentation rate higher than the hanging-wall uplift rate $(\mathrm{R} \sim 2)$ (Fig. 3 , models $1 \mathrm{~d}, 2 \mathrm{~d}$ and $3 \mathrm{~d}$ ), the main thrust zone is still steep, but is straighter than in the case where $\mathrm{R}$ $\sim 1$. Its surface dip is approximately $45-50^{\circ}$ and the uplift of its hanging wall decreases (Fig. 5). When the prekinematic sand layer is thin (Fig. 3, model 1d), this main fault zone is narrow and still corresponds to a permanent thrust. When the prekinematic sand pile is thick (Fig. 3, models $2 \mathrm{~d}$ and 3d), the main fault zone is relatively wide at the base before it narrows above. Accordingly, it can be interpreted as several temporary reverse faults that are finally replaced by a more permanent single thrust. This permanent thrust strongly offsets the synkinematic sediments, which display a drag fold on its way to the surface. The growth strata overlapping its hanging wall are also partly offset by the secondary faults that are sealed one by one at depth by the deposits when their motion stops. In these models, the prekinematic and synkinematic layers are always parallel and nearly horizontal. Hence, 
the only way to differentiate them from one another is their constant or changing thickness across the fault zones.

In experiments with a sedimentation rate a few times higher than the hanging-wall uplift rate ( $\mathrm{R}>$ 2) (Fig. 4, model 2e), the overall geometry is comparable to the one observed in the models with $\mathrm{R}$ close to 2, but the upper part of the main permanent single thrust is deflected downwards. At the model surface, the dip of this fault recovers a classical value for a thrust ramp of $30-40^{\circ}$ and its hanging wall is much less uplifted than in the experiments with less sedimentation (Fig. 5).

In this group of brittle experiments, the maximum surface dip and hanging-wall uplift of the main thrust zone reach $51^{\circ}$ and $2.4 \mathrm{~cm}$ respectively for each prekinematic sand thickness (Fig. 5). Furthermore, these maximum values are always attained for a ratio $\mathrm{R}$ ranging from 1 to 2 .

\section{Brittle-ductile models with different sand thicknesses}

In a second group of experiments, the models are brittle-ductile and initially made up of a 1 cm-thick silicone layer, overlain by a 1,2 or $3 \mathrm{~cm}$-thick prekinematic sand layer (Figs. 6, 7 and 8). In these models, the main thrust zone is still a single and permanent fault zone. Above this fault zone, the hanging wall is bent and can be affected by a single and permanent secondary backthrust zone. The deformation is thus characterized by translations along faults and rotation with layer bending between them. However, as in the first group of experiments, the deformation pattern varies according to the prekinematic sand thickness and the synkinematic sedimentation rate.

In these brittle-ductile experiments, the hanging-wall bending of the main thrust zone decreases and the secondary fault zone appears when the prekinematic sand thickness increases (Fig. 6 , models 4, 5 and 6). The hanging-wall bending also slightly decreases and the secondary fault zone develops when the synkinematic sedimentation rate increases (Figs. 6 and 7, models a, b, c, d and e). As a consequence, the symmetry of the deformation pattern in the brittle-ductile models increases with their total sand thickness.

In experiments without synkinematic sedimentation $(\mathrm{R}=0$ ) (Fig. 6 , models $4 \mathrm{a}$, 5a and 6a), the main thrust zone can be interpreted as a single and permanent fault with a ramp-and-flat geometry and a surface dip of $0-10^{\circ}$ (Fig. 9A). Additionally, when the prekinematic sand pile is thin (Fig. 6, model 
4a), a minor thrust propagates within the footwall of the main fault. In all of these experiments without sedimentation, the horizontal offset of the main thrust is large and its hanging wall is curved above its upper flat. As a result, the overall structure mimics a fault-bend fold. At the extrados of this fold, normal faults occasionally develop (Fig. 6, model 5a).

In experiments with a sedimentation rate lower than the hanging-wall uplift rate $(\mathrm{R} \sim 1 / 2)$ (Fig. 6, models $4 \mathrm{~b}, 5 \mathrm{~b}$ and $6 \mathrm{~b}$ ), the overall deformation is similar to the one observed in the models without sedimentation $(\mathrm{R}=0)$. However, the upper part of the main thrust zone is steeper. Its surface dip ranges between 5 and $25^{\circ}$ and its hanging-wall uplift is slightly amplified accordingly (Fig. 9). Moreover, in the models with a thin prekinematic sand layer (Fig. 6, model 4b), no minor thrust developed at the footwall of the main fault zone. When the prekinematic sand pile is thick (Fig. 6, models $5 \mathrm{~b}$ and $6 \mathrm{~b}$ ), the main thrust zone is also wider than in the case where $\mathrm{R}=0$. As for the purely brittle experiments, this zone is interpreted as either a broad single fault or a few thrust segments. At their footwall, the synkinematic strata are flat-lying. In contrast, the growth strata deposited on their hanging wall display a cumulative wedge system with offlap terminations (Fig. 6, model 4b), unless they are limited by a secondary thrust zone as in the models with the thickest prekinematic sand layers (Fig. 6, models 5b and 6b).

In experiments with a sedimentation rate close to the hanging-wall uplift rate ( $\mathrm{R} \sim 1$ ) (Fig. 6, models $4 c, 5 c$ and $6 c$ ), the main thrust zone widens and becomes steeper. Its surface dip classically reaches $50^{\circ}$ and can exceed $65^{\circ}$ (Fig. 9A). This leads to a strong uplift of the hanging wall (Fig. 9B). When the prekinematic sand pile is thin (Fig. 6, model 4c), the main thrust zone is wide at the base before it narrows above. It is interpreted as a few early temporary faults replaced by a permanent single thrust. When the prekinematic sand layer is thick (Fig. 6, models $5 \mathrm{c}$ and $6 \mathrm{c}$ ), the main thrust zone has a triangular shape up against the synkinematic sediments. It corresponds to a series of several temporary thrusts developed in break-back sequence with an increasing dip (Fig. 8). As a result, the overall structure mimics a fault-propagation fold, especially when the prekinematic sand thickness is intermediate (Fig. 6, model 5c). At the footwall of the main fault zone, the synkinematic layers that progressively seal the first temporary thrusts are flat-lying or slightly overturned. On the hanging wall, the growth strata can display a marked cumulative wedge system with onlap terminations, as in the 
models with the thinnest prekinematic sand pile (Fig. 6, model 4c). However, this cumulative wedge system becomes less clear when the prekinematic sand thickness increases (Fig. 6, models 5c and 6c).

In experiments with a sedimentation rate higher than the hanging-wall uplift rate $(\mathrm{R} \sim 2)$ (Fig. 6 , models $4 \mathrm{~d}, 5 \mathrm{~d}$ and $6 \mathrm{~d})$, the main thrust zone is still steep. Its surface dip is approximately $50-60^{\circ}$ and the uplift of its hanging wall remains high (Fig. 9). When the prekinematic sand layer is thin (Fig. 6 , model $4 \mathrm{~d}$ ), this fault zone is narrow, concave upwards to the base, and convex to the top. It can be interpreted as a permanent steep thrust fault that deflects towards the surface. When the prekinematic sand pile is thick (Fig. 6, models 5d and 6d), the main thrust zone is relatively wider at the base than at the top. Instead, it corresponds to a few temporary reverse faults replaced by a more permanent single thrust. This permanent thrust strongly offsets the synkinematic sediments, which display a drag fold on its way to the surface. On the other hand, the growth strata overlapping the hanging wall display a cumulative wedge system.

In experiments with a sedimentation rate that is a few times higher than the hanging-wall uplift rate $(\mathrm{R}>2)$ (Fig. 7, model 5e), the overall geometry resembles the one observed in the models with $\mathrm{R}$ close to 2, but the upper part of the main permanent single thrust is deflected downwards. The higher the sedimentation rate, the flatter the upper part of the thrust. Thus when $\mathrm{R}$ increases, the surface dip of the main fault zone decreases to recover a classical value for a thrust ramp of $30-40^{\circ}$ (Fig. 9A), while its hanging-wall uplift drops (Fig. 9B).

In this group of brittle-ductile models, the maximum surface dip and hanging-wall uplift of the main thrust zone have different values according to the prekinematic sand thickness (Fig. 9). The highest dips reached in the models with a 1,2 and $3 \mathrm{~cm}$-thick prekinematic sand layer are $68.5,55$ and $53^{\circ}$, respectively. The corresponding hanging-wall uplifts are $3.9,3.1$ and $3 \mathrm{~cm}$, with these maximum values attained for an approximate ratio $\mathrm{R}$ of $1,2.5$ and 3 .

\section{Brittle-ductile models with different silicone thicknesses}

In a third group of experiments, the models are also brittle-ductile and initially composed of a 1, 2 or $3 \mathrm{~cm}$-thick silicone layer, overlain by a $2 \mathrm{~cm}$-thick prekinematic sand layer (Fig. 10). In these models, the main thrust zone is again a single and permanent fault zone over which the hanging wall is 
bent. When it develops, the secondary backthrust zone is single and also permanent. The deformation is thus marked by translations along faults and rotations with layer bending between them. However, as in the two previous groups of experiments, the deformation pattern changes according to the silicone thickness and the synkinematic sedimentation rate.

In these brittle-ductile models, the hanging-wall bending of the main thrust zone decreases and the secondary fault zone appears when the basal silicone thickness decreases (Fig. 10, models 7, 8 and 5). The hanging-wall bending also decreases and the secondary fault zone develops when the synkinematic sedimentation rate increases (Fig. 10, models a, b, c and d). As a consequence, the symmetry of the deformation pattern in the brittle-ductile models increases with the total sand thickness, whereas it decreases with the thickness of the silicone.

In experiments without synkinematic sedimentation $(R=0)($ Fig. 10 , models $7 a, 8 a$ and $5 a)$, the main fault zone is once again interpreted as a single and permanent thrust with a ramp-and-flat geometry and a surface dip of $0-10^{\circ}$ (Fig. 11A). The horizontal offset of this thrust is large and its hanging wall is bent above its upper flat. The resulting overall structure mimics a fault-bend fold.

In experiments with a sedimentation rate lower than the hanging-wall uplift rate $(\mathrm{R} \sim 1 / 2)$ (Fig. 10, models 7b, $8 \mathrm{~b}$ and $5 \mathrm{~b}$ ), the general structure is comparable to the one observed in the models without sedimentation $(\mathrm{R}=0)$, but the main thrust zone is steeper and wider. It corresponds to either a broad single fault or several thrust segments. Its surface dip ranges between 5 and $25^{\circ}$ and its hangingwall uplift is slightly amplified (Fig. 11). At the footwall of the main thrust zone, the synkinematic strata are flat-lying. In contrast, the growth strata deposited on its hanging wall display a cumulative wedge system with onlap terminations (Fig. 10, models $7 \mathrm{~b}$ and $8 \mathrm{~b}$ ), unless they are limited by the secondary thrust zone as in the models with the thinnest silicone layer (Fig. 10, model 5b).

In experiments with a sedimentation rate close to the hanging-wall uplift rate $(\mathrm{R} \sim 1)$ (Fig. 10, models $7 \mathrm{c}, 8 \mathrm{c}$ and $5 \mathrm{c}$ ), the main thrust zone widens, becomes steeper and can be interpreted as a series of temporary thrusts developed in break-back sequence. Its surface dip is classically around $50^{\circ}$ and its hanging wall is clearly uplifted (Fig. 11). At the footwall of this main thrust zone, the synkinematic layers, which progressively sealed the first faults, are flat-lying or slightly overturned. On the hanging wall, the growth strata can display a marked cumulative wedge system with onlap terminations, as in 
the models with the thickest silicone layer (Fig. 10, model 7c). However, this cumulative wedge system becomes less clear when the silicone thickness decreases (Fig. 10, models 5c and 6c).

In experiments with a sedimentation rate that is higher than the hanging-wall uplift rate $(\mathrm{R} \sim$ 2) (Fig. 10, models $7 d, 8 d$ and $5 d$ ), the main thrust zone is relatively wider at the base than at the top and is interpreted as several temporary reverse faults replaced by a more permanent single thrust. Its surface dip ranges between 45 and $55^{\circ}$, while the uplift of its hanging wall decreases more or less sharply (Fig. 11). This permanent thrust strongly offsets the synkinematic sediments, which display a drag fold on its way to the surface. On the other hand, the growth strata overlapping the hanging wall display a cumulative wedge system.

In this group of brittle-ductile models, the maximum surface dip and hanging-wall uplift of the main thrust zone has different values depending on the silicone thickness (Fig. 11). The highest dips reached in the models with a 1,2 and $3 \mathrm{~cm}$-thick silicone layer are 55, 49 and $48^{\circ}$, respectively. The corresponding hanging-wall uplifts are $3.1,3$ and $2.7 \mathrm{~cm}$, with these maximum values attained for an approximate ratio $\mathrm{R}$ of $2.5,1$ and 1 .

\section{Models with a changing sedimentation rate through time}

The second series of experiments comprises two models designed to test the influence of synkinematic deposits on compressive growth structures according to their changes in sedimentation rate through time. These two models are brittle-ductile and were initially made up of a $1 \mathrm{~cm}$-thick silicone layer overlain by a $2 \mathrm{~cm}$-thick prekinematic sand pile (Fig 12). They were uniformly covered by synkinematic sand, but with a changing sedimentation rate during the experiment. Thus, in a single model, the ratio $\mathrm{R}$ is alternately lower or higher than $1\left(\mathrm{~V}_{\text {sed }}<\mathrm{V}_{\text {upl }}\right.$ or $\left.\mathrm{V}_{\text {sed }}>\mathrm{V}_{\text {upl }}\right)$ over time (see Table 2 for the model parameters).

In these experiments, shortening above the VD is also accommodated by a single and permanent main thrust zone (Fig. 12). Its hanging wall is uplifted and is either covered or not by the synkinematic deposits depending on their volume through time. Besides these common geometrical 
features, the deformation pattern varies according to the temporal changes in the synkinematic sedimentation rate.

In the first models of the series, the synkinematic deposits were provided with a sedimentation rate lower than the uplift rate $(\mathrm{R}<1)$ during the first half of the experiment and higher than the uplift rate $(\mathrm{R}>1)$ during the second half (Fig. 12, model 9a). In this model, the structure and evolution of the main thrust zone change upwards depending on the sedimentation rate at its front. At the base, the prekinematic materials thrust over the synkinematic layers deposited with a sedimentation rate lower than the hanging-wall uplift rate $(\mathrm{R} \sim 1 / 2)$. Overhead, the main thrust zone has a wide triangular shape against the synkinematic layers deposited with a sedimentation rate that is higher than the hangingwall uplift rate $(\mathrm{R} \sim 2)$. At the top, the thrust zone corresponds to a steep and narrow band, which goes through the latest synkinematic deposits. On the hanging wall of this fault zone, onlap and overlap geometries are observed. From these features, we may infer that, when the sedimentation rate was low, the main thrust zone probably consisted of a flat and permanent single thrust over the contemporaneous deposits. During this period, the hanging wall was rising above the sedimentation level. Later, when the sedimentation rate became high, a series of several steep and temporary reverse faults replaced the flat thrust and developed in break-back sequence. At the same time, the synkinematic deposits progressively sealed these faults and onlapped the raised hanging wall. Lastly, when the growth strata had overlapped the hanging wall, a steep and permanent single thrust took the place of the previous temporary faults. Owing to its motion, this thrust ramp has isolated a prekinematic sand wedge within the synkinematic sediments.

In the second model, the synkinematic deposits were provided with a sedimentation rate higher than the uplift rate $(\mathrm{R}>1)$ during the first half of the experiment and lower than the uplift rate $(\mathrm{R}<1)$ during the second half (Fig. 12, model 9b). As in the previous model, the structure and evolution of the main thrust zone change upwards depending on the sedimentation rate at its front. At the base, the thrust zone has a thin triangular shape. It continues upwards as a steep and narrow band against the synkinematic pile deposited with a sedimentation rate higher than the hanging-wall uplift rate $(\mathrm{R} \sim 2)$. At the top, this narrow band flattens over the synkinematic layers deposited with a sedimentation rate lower than the hanging-wall uplift rate $(\mathrm{R} \sim 1 / 2)$. Above, the former synkinematic 
deposits are involved in a recumbent fold. On the hanging wall of the main fault zone, overlap and offlap geometries are observed. From these features, we infer that, when the sedimentation rate was high, the main thrust zone consisted of a few steep and temporary reverse faults that were rapidly replaced by a more permanent single thrust. During this period, the hanging wall was buried below overlapping synkinematic layers. Later, when the sedimentation rate became low, it seems that the active thrust ramp propagated as a thrust flat over the contemporaneous deposits. At the same time, the hanging wall began to rise above the sedimentation level and the growth strata started to display an offlap geometry.

\section{Models with a changing sedimentation rate in space}

The third series of experiments is composed of two models designed to test the influence of synkinematic deposits on compressive growth structures according to their changes in sedimentation rate in space. These models are brittle-ductile and were initially composed of a $1 \mathrm{~cm}$-thick silicone layer overlain by a $2 \mathrm{~cm}$-thick prekinematic sand pile (Figs. 13 and 14). They were covered by synkinematic sand deposited with a constant sedimentation rate during the entire shortening period, but non-uniformly in space. Thus, in a single experiment, the ratio $\mathrm{R}$ varies between $0\left(\mathrm{~V}_{\text {sed }}=0\right)$ and 1 $\left(\mathrm{V}_{\text {sed }}=\mathrm{V}_{\text {upl }}\right)$ from place to place (see Table 2 for the model parameters).

In these models, shortening above the VD is also accommodated by a single and permanent main thrust zone (Figs. 13 and 14). Its hanging wall is uplifted, as usual, and is either covered or not by synkinematic deposits depending on their volume across space. Besides these common geometrical features, the deformation pattern varies according to the spatial changes in the synkinematic sedimentation rate.

In the first models of the series, the synkinematic deposits were localized in one place at the front of the main thrust zone (Fig. 13A). They form a sand fan fed with a sedimentation rate close to the uplift rate $(\mathrm{R} \sim 1)$ at the apex and decreasing to zero $(\mathrm{R}=0)$ towards the borders. In this experiment, the structure and evolution of the main thrust zone change along strike depending on the sedimentation rate at its front. Besides the fan, where there is no sedimentation $(\mathrm{R}=0)$ (Fig. 13B, 
cross-section 10a), the main thrust zone is thin and convex upwards. It corresponds to a single and permanent thrust fault with a ramp-and-flat geometry. The overall structure, which mimics a faultbend fold with normal faults at its extrados, is very similar to the one observed in the models without sedimentation (Fig. 6, model 5a). Behind the fan edges, where the sedimentation rate is lower than the hanging-wall uplift rate $(\mathrm{R} \sim 1 / 2)$ (Fig. 13B, cross-section 10b), the main thrust zone is also convex upwards, but its upper part is broader and steeper than in the previous cross-section. It can be considered as a broad single fault or as several thrust segments. The associated overall structure resembles the structure observed in the models with homogeneous sedimentation and a ratio $\mathrm{R}$ lower than 1 (Fig. 6, model 5b). Behind the fan apex, where the sedimentation rate is close to the hangingwall uplift rate $(\mathrm{R} \sim 1)$ (Fig. 13B, cross-section 10c), the main thrust zone clearly widens upwards and becomes very steep. It can be interpreted as a series of several temporary reverse faults developed in break-back sequence with an increasing dip before being progressively sealed by the synkinematic deposits. The last of these thrusts is as steep as $70^{\circ}$ and its hanging wall is strongly uplifted and backtilted. As a result, the overall structure mimics a fault-propagation fold without normal faults at its extrados. This structure is comparable to the one observed in the models with homogeneous sedimentation and a ratio $\mathrm{R}$ close to 1 (Fig. 6, model 5c). Eventually, a slight flexure of the prekinematic sand layer may occur below the synkinematic sand load.

In the second model, the synkinematic deposits were localized in two places at the front of the main thrust zone and evenly distributed on its hanging wall (Fig. 14A). Again, the localized sediment bodies are sand fans fed with a sedimentation rate close to the uplift rate $(\mathrm{R} \sim 1)$ at their apex and decreasing to zero $(\mathrm{R}=0)$ toward their borders. In contrast, the hanging wall is entirely and horizontally covered by synkinematic sand deposited with a sedimentation rate close to the uplift rate $(\mathrm{R} \sim 1)$. As in the previous experiment, a series of cross-sections shows that the structure and evolution of the main thrust zone change along strike depending on the sedimentation rate at its front (Fig. 14B). Indeed, the thrust zone, which corresponds to a single and flat thrust besides the synkinematic sand bodies, changes into a few steep reverse faults behind. At the same time, the overall structure evolves from a fault-bend fold to a fault-propagation fold. On the hanging wall, the growth strata display a cumulative wedge system. 
In this model, two other thrusts also developed within the footwall of the main fault zone (Fig. $14 \mathrm{~A}$ and 14B). They initiated at the front of the two sand fans, where there are no synkinematic deposits, before propagating laterally and joining the main fault zone. Outside the fans, these thrusts are synthetic to the main one (Fig. 14B, cross-section 11a). Ahead the fans, they reverse and individualize a full ramp basin around the synkinematic sand bodies (Fig. 11B, cross-sections 11b and 11c). However, the thrust at the toe of the small fan disappears below the large one.

\section{Discussion}

\section{Influence of synkinematic sedimentation}

In agreement with previous studies (e.g., Tondji-Biyo, 1995; Nalpas et al., 1999; Barrier et al., 2002; Nalpas et al.; 2003; Gestain et al., 2004; Strayer et al., 2004; Pichot and Nalpas, 2009; VidalRoyo et al., 2011), the experimental results presented above suggest that synkinematic sedimentation can strongly influence the deformation of single compressive growth structures. In models, their geometry and evolution vary according to the sedimentation rate. In particular, thrusts can develop as ramp-and-flat faults, classical ramps or steep ramps, depending on the ratio $\mathrm{R}\left(\mathrm{V}_{\text {sed }} / \mathrm{V}_{\text {upl }}\right)$ between the sedimentation rate at their footwall $\left(\mathrm{V}_{\text {sed }}\right)$ and the uplift rate of their hanging wall $\left(\mathrm{V}_{\text {upp }}\right)($ Fig. 15). The latter is then more or less uplifted according to the dip and the related amount of vertical offset of the faults (Fig. 16). These types of relationships are verified regardless of the rheological profile of the models. Moreover, they can also be observed in experimental or numerical thrust wedges submitted to different amounts of sedimentation (e.g., Larroque et al., 1995; Storti and McClay, 1995; McClay and Whitehouse, 2004; Cerrina Feroni et al., 2006; Simpson, 2006; Stockmal et al., 2007; Emami et al., 2010; Wu and McClay, 2011).

When the sedimentation rate is zero $(R=0)$, thrusts propagate as single and steady faults with a ramp-and-flat trajectory upwards (Fig. 15). Their surface dip is very low (less than $10^{\circ}$ ), their vertical offset is limited, and their hanging wall is slightly uplifted (Fig. 16). Typically, the structures associated with such ramp-and-flat thrusts have a fault-bend-fold geometry. 
When the sedimentation rate is lower than the uplift rate $(\mathrm{R}<1)$, thrusts develop either as single and permanent ramps or as several temporary faults that also tend to flatten upwards (Fig. 15). The surface dip of these faults is low (less than $40^{\circ}$ ), their vertical offset is limited, and their hanging wall is slightly uplifted (Fig. 16). However, similar models with a low ratio R show that erosion at the hanging wall of thrusts tends to amplify their splitting and steepening initiated by the sedimentation at their footwall (e.g., Tondji Biyo, 1995; Casas et al., 2001).

When the sedimentation rate is close to the uplift rate $(\mathrm{R} \sim 1)$, thrusts split up into several temporary ramps (Fig. 15). They develop in break-back sequence with an increasing dip, while the synkinematic deposits progressively seal them. The latest ramps are generally steeply dipping (between 50 and $70^{\circ}$ ), their vertical offset is large, and their hanging wall is strongly uplifted (Fig. 16). As a result, the growth structures associated with these thrust ramps have a fault-propagation-fold geometry.

When the sedimentation rate is higher than the uplift rate $(\mathrm{R}>1)$, thrusts divide into several temporary faults before propagating as single and permanent ramps (Fig. 15). The surface dip of these ramps is high (between 40 and $60^{\circ}$ ), their vertical offset is large, and their hanging wall is strongly uplifted (Fig. 16).

When the sedimentation rate is much higher than the uplift rate $(\mathrm{R}>>1)$, single and permanent ramps also develop, but they flatten upwards (Fig. 15). Above a lower segment relatively steep, their surface dip approaches a more typical value for thrust faults (between 30 and $50^{\circ}$ ). They actually tend towards the geometry of faults that propagate within a prekinematic material. As a consequence, the vertical offset and hanging-wall uplift of these thrust remain limited (Fig. 16).

All these observations are also verified when the ratio $\mathrm{R}$ varies along strike or changes through time. A thrust flat, which develops when the sedimentation rate is low (e.g., $\mathrm{R}<1$ ), can shift to a thrust ramp, which forms in break-back sequence when the sedimentation rate increases (e.g., $\mathrm{R} \sim 1$ ). The hanging wall is then more or less uplifted according to the dip of the last active fault segment and its related amount of vertical offset. A changing sedimentation rate in space can also prevent the development of thrusts where it is high and/or drive their propagation where it is low. In that case, the 
sedimentation rate variations control the fault location and vergence (also see Mugnier et al., 1997; Duerto and McClay, 2009; Pichot and Nalpas, 2009; Simpson, 2010; Smit et al., 2010).

In natural conditions, compressive growth structures can occur in a variety of geological settings from orogenic systems to accretionary wedges or gravity-driven compression belts on passive margins. In these natural systems, break-back sequences of steep thrust splays are frequently observed at the front of compressive growth structures (e.g., Burbank et al., 1992; Deramond et al., 1993; Artoni and Casero, 1997; Mugnier et al., 1998; Millán Garrido et al., 2000; Barrier et al., 2002; Barrier et al., 2010; Wu and McClay, 2011). Detailed studies further show that the occurrence of such break-back sequences is probably correlated with changes in sedimentation rate along strike (Barrier et al., 2002) or through time (Barrier et al., 2010). As argued by Barrier et al. (2002), this implies that steep thrusts are not necessarily the result of transpression involving strike-slip motions or of inversion of earlier normal faults. Similarly, spatiotemporal variations of the fault geometry are not necessarily linked to rheological changes or structural heritage. Such features can also be forced by synkinematic sedimentation and changes in its rate in space and time.

Therefore we propose that, in many cases, the geometrical complexities of synsedimentary thrusts must be interpreted with regards to the changes in the ratio $\mathrm{R}\left(\mathrm{V}_{\text {sed }} / \mathrm{V}_{\text {upl }}\right)$ between the sedimentation rate at their footwall $\left(\mathrm{V}_{\text {sed }}\right)$ and the uplift rate of their hanging wall $\left(\mathrm{V}_{\text {upl }}\right)$. In other words, knowing this ratio and its variations, both of which can be estimated based on the internal stratigraphy and geometry of the growth strata (see Riba, 1976; Burbank and Vergés, 1994; Artoni and Casero, 1997), is important to understand the evolution of growth structures. However, variations in the ratio $\mathrm{R}$ in natural systems are not necessarily related to changes in sedimentation rate as in the models. They may also be due to changes in uplift rate. Nevertheless, our experimental observations are carried out based on the ratio between the two rates, so they must be valid regardless of the changing parameter. Consequently, we believe that the relationships highlighted in the models between synkinematic sedimentation and the geometry and evolution of compressive structures can be used to better reconstruct their deformation in the field or on seismic profiles. 
Our experimental results suggest that the deformation of single compressive growth structures also depends on the rheology of the deformed layers. Indeed, even if strongly influenced by the sedimentation rate and its changes in space and time, the geometry of the models also varies according to their prekinematic rheological profile. In the experiments, the amount of faulting and folding changes with the thickness of the basal silicone (ductile) and overlying sand (brittle) layers (Fig. 15). The symmetry of the deformation is then more or less developed according to this amount of faulting and folding.

In brittle models, shortening is accommodated by translation along faults and minor rotations without layer bending between them. Hence, the prekinematic and synkinematic strata are parallel and the only way to differentiate them from one another is their constant or changing thickness across the faults. In these experiments, the secondary thrusts are less numerous and the overall deformation is more symmetrical when the prekinematic sand thickness increases. In contrast, shortening in brittleductile models is accommodated by translation along faults and rotation with layer bending between them. As a result, the growth strata deposited on the hanging wall of the main thrust zone usually display progressive unconformities. In these models, the bending of the hanging wall decreases, a secondary fault zone appears and the overall deformation is more symmetrical when the prekinematic sand thickness increases or when the silicone thickness decreases.

Previous experimental studies have analyzed the mechanical behaviour of brittle-ductile compressive systems in terms of the strength of the brittle and ductile layers (e.g., Bonini, 2001; Smit et al., 2003; Pichot and Nalpas, 2009). The same approach can be applied here. At the beginning of the experiments, the maximum shear stress $\tau b$ at the base of the prekinematic brittle layer is given by

$$
\tau b=2 . \rho . g . T b,
$$

where $\rho$ is the sand density, $\mathrm{g}$ is the acceleration due to gravity, and $\mathrm{Tb}$ is the thickness of the prekinematic sand layer. Consequently, for a given sand density, $\tau b$ is a function of the brittle layer thickness. At the onset of deformation, the mean shear stress $\tau d$ in the ductile layer is then given by

$$
\tau d=\mu . V_{\text {shorr }} / \mathrm{Td},
$$


where $\mu$ is the viscosity, $\mathrm{V}_{\text {short }}$ is the shortening rate, and $\mathrm{Td}$ is the thickness of the silicone layer. Therefore, for a given viscosity and displacement rate, $\tau d$ is an inverse function of the ductile layer thickness. Finally, the mechanical behaviour of brittle-ductile systems can be characterized using the product $\tau b . \tau d$ and the ratio $\tau b / \tau d$ between these two shear stresses. In fact, the deformation style of such systems depends on the coupling between the brittle and ductile layers (also known as BD coupling), which is controlled by their absolute and relative strengths. The higher the product $\tau b . \tau d$ and the lower the ratio $\tau \mathrm{b} / \tau \mathrm{d}$ (i.e. the thicker the brittle layers and the thinner the ductile ones), the less efficient the décollements in the ductile levels. As a consequence, the stronger the BD coupling between these ductile levels and their brittle covers. On the other hand, the lower the product $\tau b . \tau d$ and the higher the ratio $\tau b / \tau d$ (i.e. the thinner the brittle layers and the thicker the ductile ones), the more efficient the décollements in the ductile levels and the weaker the BD coupling between these levels and their brittle covers.

The shear stress ratio of the experiments can be plotted against their shear stress product in order to visualize the evolution of their absolute and relative brittle-ductile strengths when the prekinematic rheological profile changes (Fig. 17). Any increase in the prekinematic sand thickness Tb leads to a large increase in the product $\tau b . \tau d$, which largely balances a small increase in the ratio $\tau \mathrm{b} / \tau \mathrm{d}$ and generates a strong increase in the BD coupling. In contrast, any increase in the silicone thickness $\mathrm{Td}$ leads to a large decrease in the product $\tau \mathrm{b} . \tau \mathrm{d}$, along with a large increase in the ratio $\tau \mathrm{b} / \tau \mathrm{d}$, both of which result in a decrease in the BD coupling. In addition to these prekinematic changes, BD coupling can also vary through time when synkinematic deposits are provided. In experiments with synkinematic sedimentation, the sand thickness (i.e. the product $\tau \mathrm{b} . \tau \mathrm{d}$ ) increases during shortening and leads to a strengthening of the BD coupling. The higher the sedimentation rate, the stronger the BD coupling becomes through time.

These prekinematic or synkinematic variations in BD coupling successfully account for the structural style of the models and the geometry of their growth strata (Fig. 15). When BD coupling is weak, the basal décollement level is efficient and the deformation is more continuous. The associated structures are asymmetric with a large bending component and no secondary thrust zone. On their 
hanging walls, the growth strata display marked progressive unconformities. When BD coupling is strong, the basal décollement level loses its efficiency and the deformation is more discontinuous. The associated structures become symmetric with a small bending component and the development of a secondary thrust zone. In such situations, the hanging-wall progressive unconformities are much less developed.

Additionally, the rheological profile of the deformed materials also impacts the influence of synkinematic sedimentation on compressive growth structures. Qualitatively, the splitting and steepening of synsedimentary thrusts do not depend on model rheology, since they occur within both brittle and brittle-ductile experiments. Quantitatively, however, the fault response to synkinematic deposits changes according to the prekinematic rheological layering of the system (Fig. 18). Where there is no basal décollement level, the magnitude of thrust splitting and steepening is a function of the ratio $\mathrm{R}$ only. Indeed, in brittle models, the maximum surface dip of the main thrust zone $\left(\alpha_{\max } \sim 50^{\circ}\right)$ and the ratio $\mathrm{R}$ for which this maximum dip is reached $\left(\mathrm{R}_{\max } \sim 1.5\right)$ are similar irrespective of the prekinematic sand thickness $\mathrm{Tb}$. In contrast, where there is a basal décollement level, the magnitude of thrust splitting and steepening is a function of the ratio $\mathrm{R}$, along with the prekinematic rheology. In brittle-ductile experiments, the maximum surface dip of the main thrust zone and the corresponding ratio $\mathrm{R}$ have different values $\left(48^{\circ}<\alpha_{\max }<68.5^{\circ}\right.$ and $\left.1<\mathrm{R}_{\max }<3\right)$ according to the prekinematic sand and silicone thicknesses $\mathrm{Tb}$ and $\mathrm{Td}$. Actually, the maximal fault steepening decreases when the ratio $\tau \mathrm{b} / \tau \mathrm{d}$ increases (Fig. 18A), whereas the ratio $\mathrm{R}$ for which this maximal steepening occurs increases with the product $\tau$ b. $\tau$ d (Fig. 18B). In other words, the thicker the prekinematic brittle and ductile layers, the weaker the influence of synkinematic sedimentation on thrust faults. Moreover, the thicker the prekinematic brittle layer or the thinner the ductile layer, the higher the ratio $\mathrm{R}$ for which this influence is maximal

Eventually, the fault response to synkinematic deposits is also affected by their rheology. When a ductile layer is deposited at the front of a thrust, the latter does not steepen as for brittle deposits, but it flattens within this décollement level (Nalpas et al., 2003; Gestain et al., 2004). As a result, a triangle zone forms with a thrust slice of prekinematic materials inserted into the ductile layer. 
At first glance, this thrust slice could be confused with a thrust wedge isolated within the synkinematic deposits during the changes in sedimentation rate through time (Fig. 12, model 9a). However, they are associated with different growth-strata geometries. The deposits at the front of the thrust zone are folded into a progressive unconformity when they lie above a synkinematic décollement layer, whereas they are flat-lying in the absence of such a décollement level. Therefore, the rheology of the deformed materials appears to be a key parameter, along with the ratio $\mathrm{R}$ and its changes in space and time, to better understand the geometry and evolution of compressive growth structures and to improve their interpretation.

\section{Conclusions}

The experimental results presented here suggest that synkinematic sedimentation can strongly influence the deformation of single compressive growth structures. Indeed, their geometry and evolution seem to vary according to the sedimentation rate. The number and dip of their frontal thrust segments change with the ratio $R\left(V_{\text {sed }} / V_{\text {upl }}\right)$ between the sedimentation rate at the footwall of these faults $\left(\mathrm{V}_{\text {sed }}\right)$ and the uplift rate of their hanging wall $\left(\mathrm{V}_{\text {upl }}\right)$. The latter is then more or less uplifted depending on the dip and the related vertical offset of the thrusts. It can be noticed that these rules are verified when the ratio $R$ varies across space or changes through time. The main outcomes of this study are as follows:

1) When the sedimentation rate is zero $(\mathrm{R}=0)$, thrusts propagate as single and steady faults with a ramp-and-flat trajectory upwards. Their surface dip is very low (less than $10^{\circ}$ ), their vertical offset is limited, and their hanging wall is slightly uplifted. Typically, the structures associated with such ramp-and-flat thrusts have a fault-bend-fold geometry.

2) When the sedimentation rate is lower than the uplift rate $(\mathrm{R}<1)$, thrusts develop as either single and permanent ramps or several temporary faults that tend to flatten upwards. The surface dip of these faults is low (less than $40^{\circ}$ ), their vertical offset is limited, and their hanging wall is slightly uplifted. 
3) When the sedimentation rate is close to the uplift rate $(\mathrm{R} \sim 1)$, thrusts split up into several temporary ramps. They develop in break-back sequence with an increasing dip, while the synkinematic deposits progressively sealed them. The dip of these ramps is often very high (between 50 and $70^{\circ}$ ), their vertical offset is large, and their hanging wall is strongly uplifted. As a result, the growth structures associated with such thrust ramps have a fault-propagation-fold geometry.

4) When the sedimentation rate is higher than the uplift rate $(R>1)$, thrusts divide into several temporary faults before propagating as single and permanent ramps. The surface dip of these ramps is high (between 40 and $60^{\circ}$ ), their vertical offset is large, and their hanging wall is strongly uplifted.

5) When the sedimentation rate is much higher than the uplift rate $(R>>1)$, single and permanent ramps also develop, but they flatten upwards. Above a relatively steep lower segment, their surface dip approaches a more typical value for thrust faults (between 30 and $50^{\circ}$ ). As a consequence, the vertical offset and hanging-wall uplift of these thrust remain limited.

6) According to the previous points, changes along strike or through time of the ratio $R$ at the front of compressive structures affect their three-dimensional geometry and evolution. For instance, a thrust flat, which develops when the sedimentation rate is low $(\mathrm{R}<1)$, can shift to a thrust ramp, which forms in break-back sequence when the sedimentation rate increases $(\mathrm{R} \sim 1)$.

In addition to the ratio $\mathrm{R}$ and its changes in space and time, the rheological profile of the deformed materials also affects the geometry and evolution of single compressive growth structures. Their structural style, as well as the synsedimentary splitting and steepening of the associated thrusts, varies according to the occurrence and strength of brittle and ductile layers.

7) Without an efficient décollement level at the base of the system, shortening is accommodated by faulting and minor layer bending. In contrast, with an efficient basal décollement level, it occurs by faulting and folding. The associated structures are then more or less symmetric due to the development of either two conjugate thrust zones or a single one only.

8) Finally, the rheological layering of the system also impacts the influence of synkinematic sedimentation on thrust faults. When brittle sediments are deposited at the front of a thrust, it always splits up and steepens depending on the ratio $\mathrm{R}$ (see points 1 to 6 ). However, the thickness of the prekinematic brittle and ductile layers controls the maximum dip reached by this fault. The thinner 
these layers, the higher this maximum dip. Moreover, the thinner the basal décollement level and the thicker its prekinematic brittle cover, the higher the ratio $\mathrm{R}$ for which this dip is observed.

These experimental outcomes imply that many of the geometrical and kinematical complexities of natural growth thrusts and folds must be linked to interactions between deformation and sedimentation processes, or to the rheology of the involved materials.

\section{Acknowledgments}

This work was funded by the French CNRS, ELF Exploration-Production and TOTAL. The authors would like to thank Jean-Jacques Kermarrec for his valuable technical assistance in the laboratory. Aknowledgements are also due to Sara Mullin for its editorial assistance, which has improved the language quality of this article. Finally, we are grateful to two anonymous reviewers for their constructive comments and suggestions. This is IPGP contribution 3374.

\section{References}

Allemand, P., Brun, J.P., Davy, P. and Van Den Driessche, J., 1989. Symétrie et assymétrie des rifts et mécanismes d'amincissement de la lithosphère. Bulletin de la Société Géologique de France, 3: 445-451.

Arenas, C., Millán, H., Pardo, G. and Pocoví, A., 2001. Ebro Basin continental sedimentation associated with late compressional Pyrenean tectonics (north-eastern Iberia): controls on basin margin fans and fluvial systems. Basin Research, 13(1): 65-89.

Artoni, A. and Casero, P., 1997. Sequential balancing of growth structures, the late Tertiary example from the central Apennine. Bulletin de la Société géologique de France, 168(1): 35-49.

Avouac, J.P. and Burov, E.B., 1996. Erosion as a driving mechanism of intracontinental mountain growth. Journal of Geophysical Research, 101(B8): 17 747-17 769.

Ballard, J.F., Brun, J.P., Van Den Driessche, J. and Allemand, P., 1987. Propagation des chevauchements au-dessus des zones de décollement : Modèles expérimentaux. Comptes Rendus de l'Académie des Science de Paris, Série IIA, 305: $1249-1253$. 
Barrier, L., Nalpas, T., Gapais, D., Proust, J.N., Casas, A.M. and Bourquin, S., 2002. Influence of syntectonic sedimentation on thrust geometry. Field exemples from the Iberian Chain (Spain) and analogue modelling. Sedimentary Geology, 146(1-2): 91-104.

Barrier, L., Proust, J.N., Nalpas, T., Robin, C. and Guillocheau, F., 2010. Control of alluvial sedimentation at forelandbasin active margins: A case study from the northeastern Ebro Basin (southeastern Pyrenees, Spain). Journal of Sedimentary Research, 80: 728-749.

Beaumont, C., Fullsack, P. and Hamilton, J., 1994. Styles of crustal deformation in compressional orogens caused by subduction of the underlying lithosphere. Tectonophysics, 232: 119-132.

Bonini, M., 2001. Passif roof thrusting and forelandward fold propagation in scaled brittle-ductile physical models of thrust wedges. Journal of Geophysical Research, 106(B2): 2 291-2 311.

Bonnet, C., Malavieille, J. and Mosar, J., 2007. Interactions between tectonics, erosion and sedimentation during the recent evolution of the Alpine orogen: analogue modeling insights. Tectonics, 26: TC6016. doi:10.1029/2006TC002048

Bonnet, C., Malavieille, J. and Mosar, J., 2008. Surface processes versus kinematics of thrust belts: Impact on rates of erosion, sedimentation, and exhumation - Insights from analogue models. Bulletin de la Scociété Géologique de France, 179(3): 297-314.

Braun, J. and Pauselli, C., 2004. Tectonic evolution of the Lachlan Fold Belt, southeastern Australia: constraints from coupled numerical models of crustal deformation and surface erosion driven by subduction of the underlying mantle. Physics of the Earth and Planetary Interiors, 141: 281-301.

Brun, J.P., 2002. Deformation of the continental lithosphere: Insights from brittle-ductile models. In: S. de Meer, M.R. Drury, J.H.P. de Bresser and G.M. Pennock (Editors), Deformation Mechanisms, Rheology and Tectonics: Current Status and Future Perspectives. Geological Society of London Special Publications, pp. 355-370.

Burbank, D.W., Puidefàbregas, C. and Muñoz, J.A., 1992. The chronology of the Eocene tectonic and stratigraphic developement of the eastern Pyrenean Foreland basin, northeast Spain. Geological Society of Ammerica Bulletin, 104: 1101-1120.

Burbank, D.W. and Vergés, J., 1994. Reconstruction of topography and related depositional systems during active thrusting. Journal of Geophysical Research, 99: 20281-20297.

Casas, A.M., Gapais, D., Nalpas, T., Besnard, K. and Roman Berdiel, T., 2001. Analogue models of transpressive systems. Journal of Structural Geology, 23(5): 733-743.

Cerrina Feroni, A. Bonini, M., Martinelli, P., Moratti, G., Sani, F., Montanari, D. and Del Ventisette, C., 2006. 
Lithological control on thrust-related deformation in the Sassa-Guardistallo Basin (Northern Apennines hinterland, Italy). Basin Research, 18: 301-321.

Costa, E. and Vendeville, B.C., 2002. Experimental insights on the geometry and kinematics of fold-and-thrust belts above weak, viscous evaporitic décollement. Journal of Structural Geology, 24: 1729-1739.

Cotton, J.T. and Koyi, H.A., 2000. Modeling of thrust fronts above ductile and frictional detachments: Application to structures in the Salt Range and Potwar Plateau, Pakistan. Geological Society of America Bulletin, 112(3): 351363.

Davy, P. and Cobbold, P.R., 1991. Experiments on shortening of a 4-layer model of the continental lithosphere. Tectonophysics, 188: 1-25.

DeCelles, P.G. and Mitra, G., 1995. History of the Sevier orogenic wedge in terms of critical taper models, northeast Utah and southwest Wyoming. Geological Society of America Bulletin, 107(4): 454-462.

Deramond, J., Souquet, P., Fondecave-Wallez, M.J. and Specht, M., 1993. Relationships between thrust tectonics and sequence stratigraphy surfaces in foredeeps: Model and examples from the Pyrenees (Cretaceous-Eocene, France, Spain). In: G.D. Williams and A. Dobb (Editors), Tectonics and seismic sequence strtigraphy. Geological Society Special Publications, 71: 193-219.

Duerto, L. and McClay, K., 2009. The role of syntectonic sedimentation in the evolution of doubly vergent thrust wedges and foreland folds. Marine and Petroleum Geology, 26: 1051-1069.

Elliott, D., 1976. The energy balance and deformation mechanisms of thrust sheets. Philosophical Transactions of the Royal Society of London, Series A, 283: 289-312.

Emami, H., Vergès, J., Nalpas, T., Gillespie, P., Sharp, I., Karpuz, R., Blanc, E.P. and Goodarzi, G.H., 2010. Structure of the Mountain Front Flexure along the Anaran anticline in the Pusht-e Kuh Arc (NW Zagros, Iran): insights from sand box models. Geological Society of London Special Publications, 330: 155-178.

Faugère, E. and Brun, J.P., 1984. Modélisation expérimentale de la distension continentale. Comptes Rendus de l'Académie des Science de Paris, Série IIA, 299: 365-370.

Fillon, C., Huismans, R. and van der Beek, P., 2013. Syntectonic sedimentation effects on the growth of fold and-thrust belts. Geology, 41(1): 83-86. doi: 10.1130/G33531.1

Gestain, V., Nalpas, T., Rouby, D. and Barrier, L., 2004. Rôle des niveaux incompétents syn-cinématiques sur l'évolution des zones chevauchantes. Modélisation analogique. Bulletin de la Société Géologique de France, 175(4): 351359.

Graveleau, F., Malavieille, J. and Dominguez, S., 2012. Experimental modelling of orogenic wedges: A review. 
Tectonophysics, 538-540: 1-66. doi: 10.1016/j.tecto.2012.01.027

Hardy, S., Duncan, C., Masek, J. and Brown, D., 1998. Minimum work, fault activity and the growth of critical wedges in fold and thrust belts. Basin Research, 10: 365-373.

Hilley, G.E., Strecker, M.R. and Ramos, V.A., 2004. Growth and erosion of fold-and-thrust belts with an application to the Aconcagua fold-and-thrust belt, Argentina. Journal of Geophysical Research, 109: B01410.

Hubbert, M.K., 1937. Theory of scale models as applied to the study of geological models. Geological Society of America Bulletin, 48: 1 459-1 520.

Johnson, M.R.W., 1981. The erosion factor in the emplacement of the Keystone thrust sheet (South East Nevada) across a land surface. Geological Magazine, 118(5): 501-507.

King, G.C., Stein, R.S. and Rundle, J.B., 1988. The growth of geological structures by repeated earthquakes 1: Conceptual Framework. Journal of Geophysical Research, 93(B11): 13 307-13 319.

Konstantinovskaia, E. and Malavieille, J., 2005. Erosion and exhumation in accretionary orogens: Experimental and geological approaches. Geochemistery Geophysics Geosystems, 6(2): Q02006.

Konstantinovskaya, E. and Malavieille, J., 2011. Thrust wedges with décollement levels and syntectonic erosion: A view from analog models. Tectonophysics, 502: 336-350. doi:10.1016/j.tecto.2011.01.020

Koons, P.O., 1990. Two-sided orogen: Collision and erosion from sandbox to the southern Alps, New Zealand. Geology, 18: $679-682$.

Larroque, C., Calassou, S., Malavieille, J. and Chanier, F., 1995. Experimental modeling of forearc basin development during accretionary wedge growth. Basin Research, 7: 277-268.

Liu, H., McClay, K.R. and Powell, D., 1992. Physical models of thrust wedges. In: K.R. McClay (Editor), Thrust tectonics. Chapman \& Hall, London, pp. 71-81.

Malavieille, J., 1984. Modélisation expérimentale des chevauchements imbriqués : application aux chaînes de montagnes. Bulletin de la Société géologique de France, XXVI(1): 129-138.

Malavieille, J., 2010. Impact of erosion, sedimentation, and structural heritage on the structure and kinematics of orogenic wedges: Analog models and case studies. GSA Today, 20(1). doi: 10.1130/GSATG48A.1

McClay, K.R. and Whitehouse, P.S., 2004. Analog modeling of doubly vergent thrust wedges. In: K.R. McClay (Editor), Thrust tectonics and hydrocarbon systems. American Association of Petroleum Geologists Memoir, 82: 184-206.

Meigs, A.J. and Burbank, D.W., 1997. Growth of the South Pyrenean orogenic wedge. Tectonics, 16(2): 239-258.

Merle, O. and Abidi, N., 1995. Approche expérimentale du fonctionnement des rampes émergeantes. Bulletin de la Scociété Géologique de France, 166(5): 439-450. 
Millán Garrido, H. et al., 2000. Actividad tectónica registrada en los depósitos terciarios del frente meridional del Pirineo central. Revista de la Sociedad Geologica de España, 13(2): 279-300.

Mugnier, J.L. et al., 1997. Thrust geometry controlled by erosion and sedimentation: A view from analogue models. Geology, 25(5): 427-430.

Mugnier, J.L., Delcaillau, B., Huyghe, P. and Leturmy, P., 1998. The break-back thrust splay of the main Dun Thrust (Himalayas of Western Nepal): Evidence of an intermediate displacement scale between earthquake slip and finit geometry of thrust systems. Journal of Structural Geology, 20(7): 857-864.

Nalpas, T., Gapais, D., Vergès, J., Barrier, L., Gestain, V., Leroux, G., Rouby, D. and Kermarrec, J.J., 2003. Effects of rate and nature of synkinematic sedimentation on the growth of compressive structures constrained by analogue models and field examples. In: T. McCann and A. Staintot (Editors), Tracing tectonic deformation using the sedimentary record. Geological Society of London Special Publications, 208: 307-319.

Nalpas, T., Györfi, I., Guillocheau, F., Lafont, F. and Homewood, P., 1999. Influence de la charge sédimentaire sur le développement d'anticlinaux synsédimentaires. Modélistion analogique et exemples de terrain (Bordure sud du bassin de Jaca). Bulletin de la Scociété Géologique de France, 170(5): 733-740.

Pichot, T. and Nalpas, T., 2009. Influence of synkinematic sedimentation in a thrust system with two decollement levels; Analogue modelling. Tectonophysics, 473: 466-475.

Price, N.J. and Johnson, M.R.W., 1982. A mechanical analysis of the Keystone-Muddy mountain thrust sheet in the southeast Nevada. Tectonophysics, 84: 131-150.

Raleigh, C.B. and Griggs, D.T., 1963. Effect of the toe in the mechanics of overthrust faulting. Geological Society of America Bulletin, 74: 819-830.

Ramberg, H., 1981. Gravity, Deformation and the Earth’s Crust, 2nd ed. Academic Press, London. 452 pp.

Riba, O., 1976. Syntectonic unconformities of the Alto Cardener, Spanish Pyrenees: A genetic interpretation. Sedimentary Geology, 15: 213-233.

Simpson, G.D.H., 2006. Modelling interactions between fold-thrust belt deformation, foreland flexure and surface mass transport. Basin Research, 18: 125-143.

Simpson, G.D.H., 2010. Influence of the mechanical behaviour of brittle-ductile fold-thrust belts on the development of foreland basins. Basin Research, 22: 139-156.

Smit, J., Brun, J.P. and Sokoutis, D., 2003. Deformation of brittle-ductile thrust wedges in experiments and nature. Journal of Geophysical Research, 108(B10): 2480.

Smit, J., Burg, J.P., Dolati, A. and Sokoutis, D., 2010. Effects of mass waste events on thrust wedges: Analogue 
experiments and application to the Makran accretionary wedge. Tectonics, 29: TC3003.

Stockmal, G.S., Beaumont, C., Nguyen, M. and Lee, B., 2007. Mechanics of thin-skinned fold-and-thrust belts: Insights from numerical models. In: J.W. Sears, T.A. Harms and C.A. Evenchick (Editors), Whence the Mountains ? Inquiries into the Evolution of Orogenic Systems: A Volume in Honor of Raymond A. Price. Geological Society of America Special Paper, 433: 63-98.

Storti, F. and McClay, K., 1995. Influence of syntectonic sedimentation on thrust wedges in analogue models. Geology, 23(11): 999-1 002.

Storti, F. and Salvini, F., 1996. Progressive rollover fault-propagation folding: A possible kinematic mechanism to generate regional-scale recumbent folds in shallow foreland belts. American Association of Petroleum Geologists Bulletin, 80(2): 174-193.

Storti, F., Salvini, F. and McClay, K., 2000. Synchronous and velocity-partitioned thrusting and thrust polarity reversal in experimentally produced, doubly-vergent thrust wedges: Implication for natural orogens. Tectonics, 19(2): 378396.

Strayer, L.M., Erickson, S.G. and Suppe, J., 2004. Influence of growth strata on the evolution of fault-related folds Distinct-element models. In: K.R. McClay (Editor), Thrust tectonics and hydrocarbon systems. American Association of Petroleum Geologists Memoir, 82: 413-437.

Tondji Biyo, J.J., 1995. Chevauchements et bassins compressifs. Influence de l'érosion et de la sédimentation. Mémoires de Géosciences Rennes, 59: 426 pp.

Vidal-Royo, O., Hardy, S. and Muñoz, J.A., 2011. The roles of complex mechanical stratigraphy and syn-kinematic sedimentation in fold development: insights from discrete-element modelling and application to the Pico del Águila anticline (External Sierras, Southern Pyrenees). Geological Society of London Special Publications, 349: 45-60.

Weijermars, R., Jackson, M.P.A. and Vendeville, B., 1993. Rheological and tectonic modeling of salt provinces. Tectonophysics, 217: 143-174.

Whipple, K.X., 2009. The influence of climate on the tectonic evolution of mountain belts. Nature Geoscience, 2, doi: 10.1038/NGEO413.

Whipple, K.X. and Meade, B.J., 2006. Orogen response to changes in climatic and tectonic forcing. Earth and Planetary Science Letters, 243: 218-228.

Willemin, J.H., 1984. Erosion and the mechanics of shallow foreland thrusts. Journal of Structural Geology, 6(4): 425432. 
Willett, S., Beaumont, C. and Fullsack, P., 1993. Mechanical model for the tectonics of doubly vergent compressional orogens. Geology, 21: 371-374.

Willett, S.D., 1999. Orogeny and orography: The effect of erosion on the structure of mountain belts. Journal of Geophysical Research, 104(B12): 28 957-28 981.

Williams, E.A., Ford, M., Vergés, J. and Artoni, A., 1998. Alluvial gravel sedimentation in a contractional growth fold setting, Sant Llorenç de Morunys, southeastern Pyrenees. In: A. Mascle, C. Puigdefàbregas, H.P. Luterbacher and M. Fernàndez (Editors), Cenozoic foreland basins of western Europe. Special Publications of the Geological Society of London, 134: 69-106.

Wu, J.E. and McClay, K., 2011. Two-dimensional Analog Modeling of Fold and Thrust Belts: Dynamic Interactions with Syncontractional Sedimentation and Erosion. In: K. McClay, J. Shaw and J. Suppe (Editors), Thrust fault-related folding. American Association of Petroleum Geologists Memoir, 94: 301-333, DOI:10.1306/13251343M9450.

\section{Figure and Table captions}

Fig. 1: Experimental apparatus and model structure (the silicone layer is optional) (modified from Barrier et al., 2002).

Fig. 2: Main geometrical features of models after deformation in surface view (A) and cross-sections (B, C and D). (A) Surface view of a model with a $1 \mathrm{~cm}$-thick basal silicone layer, a $2 \mathrm{~cm}$-thick prekinematic sand pile, and a ratio $\mathrm{R}=\mathrm{V}_{\text {sed }} / \mathrm{V}_{\text {upl }}$ close to $1 / 2$. Cross-sections of models with (B) no basal silicone layer, a $2 \mathrm{~cm}$-thick prekinematic sand layer, and a ratio $\mathrm{R}$ close to $1 \frac{1}{2}$; (C) a basal $1 \mathrm{~cm}$ thick silicone layer, a $2 \mathrm{~cm}$-thick prekinematic sand layer, and a ratio $\mathrm{R}$ close to $1 / 2$; and (D) a $1 \mathrm{~cm}$ thick basal silicone layer, a $2 \mathrm{~cm}$-thick prekinematic sand layer, and a ratio $\mathrm{R}$ close to 2 . In the crosssections, the mobile wall and mobile basal plate are symbolized by a thick black line.

Fig. 3: Cross-sections of brittle models illustrating the effect of different sedimentation rates on deformation when the prekinematic sand layer is 1,2 or $3 \mathrm{~cm}$ thick.

Fig. 4: Cross-section of a brittle model illustrating the effect of a high sedimentation rate on deformation when the prekinematic sand layer is $2 \mathrm{~cm}$ thick and the ratio $\mathrm{R}$ is close to 5 . 
Fig. 5: (A) Surface dip of the main thrust zone $\alpha$, and (B) uplift of its hanging wall $\mathrm{H}_{\text {upl }}$ according to the ratio $\mathrm{R}$ in brittle models with different prekinematic sand thicknesses $\mathrm{Tb}$. The dashed line corresponds to the mean values of the measurement clusters.

Fig. 6: Cross-sections of brittle-ductile models illustrating the effect of different sedimentation rates on deformation when the basal silicone layer is $1 \mathrm{~cm}$ thick and the prekinematic sand layer is 1,2 or $3 \mathrm{~cm}$ thick.

Fig. 7: Cross-section of a brittle-ductile model illustrating the effect of a high sedimentation rate on deformation when the basal silicone layer is $1 \mathrm{~cm}$ thick, the prekinematic sand layer is $2 \mathrm{~cm}$ thick, and the ratio $\mathrm{R}$ is close to 3.5 .

Fig. 8: Enlargement of a main thrust zone observed in a model with homogeneous sedimentation and a steady ratio R close to 1 (see Fig. 6, model 5c). With its triangular shape, this thrust zone does not correspond to a single shear strip (A). Instead, it consists of a fan-shaped series of shear bands that do not continue into the synkinematic strata (B). Consequently, it must be considered as an assemblage of temporary faults developed in a break-back sequence with an increasing dip at each depositional increment (C). In each of the figures, fault planes are preferentially drawn through small offsets of the prekinematic layer and along the upper boundary of the main thrust zone.

Fig. 9: (A) Surface dip of the main thrust zone $\alpha$, and (B) uplift of its hanging wall $\mathrm{H}_{\text {upl }}$ according to the ratio $\mathrm{R}$ in brittle-ductile models with different prekinematic sand thicknesses $\mathrm{Tb}$. The dashed lines correspond to the mean values of the measurement clusters.

Fig. 10: Cross-sections of brittle-ductile models illustrating the effect of different sedimentation rates on deformation when the basal silicone layer is 1,2 or $3 \mathrm{~cm}$ thick and the prekinematic sand layer is 2 $\mathrm{cm}$ thick. Models 5a, 5b, 5c and 5d are the same as in Figure 6.

Fig. 11: (A) Surface dip of the main thrust zone $\alpha$, and (B) uplift of its hanging wall $\mathrm{H}_{\text {upl }}$ according to the ratio $\mathrm{R}$ in brittle-ductile models with different basal silicone thicknesses $\mathrm{Td}$. The dashed lines correspond to the mean values of the measurement clusters.

Fig. 12: Cross-sections of brittle-ductile models illustrating the effect of a changing sedimentation rate through time on the deformation pattern. In the first model (model 9a), the ratio R abruptly increases 
from $1 / 2$ to 2 half-way through the experiment. In the second model (model $9 \mathrm{~b}$ ), the ratio $\mathrm{R}$ abruptly decreases from 2 to $1 / 2$ half-way through the experiment. In these models, the secondary fault zone is lacking since they were performed during summer. Hence, the laboratory temperature was higher than $20^{\circ} \mathrm{C}$ and the viscosity of the silicone putty was a little bit lower than usual. However, except for the development of the secondary thrust zone, this slight rheological modification does not significantly affect the experiment deformation.

Fig. 13: (A) Surface view and (B) cross-sections of a brittle-ductile model illustrating the effect of a changing sedimentation rate in space on the deformation pattern. In this model, the ratio $\mathrm{R}$ varies between 0 and 1 at the footwall of the main thrust zone, whereas there is no sedimentation on its hanging wall.

Fig. 14: (A) Surface view and (B) cross-sections of a brittle-ductile model illustrating the effect of a changing sedimentation rate in space on the deformation pattern. In this model, the ratio $\mathrm{R}$ varies between 0 and 1 at the footwall of the main thrust zone, whereas sedimentation is homogeneous on its hanging wall.

Fig. 15: Geometrical features of compressive growth structures according to (1) the ratio R between the sedimentation rate and the uplift rate of the hanging wall, and (2) the rheological profile of the prekinematic materials. In this table, the ratio $\mathrm{R}$ increases from top to bottom, while the shear stress product $\tau b . \tau d$ increases from left to right. The number and dip of thrust splays at the front of the structures change with the ratio $\mathrm{R}$. Their hanging walls are then more or less uplifted depending on the dip of the faults and their overall geometry mimics either a fault-bend fold or a fault-propagation fold. In addition, the amount of faulting and folding, as well as the symmetry of the deformation, changes with the thickness of the basal ductile and overlying brittle layers.

Fig. 16: Hanging-wall uplift of the main thrust zone $\mathrm{H}_{\text {upl }}$ according to its surface dip $\alpha$. The light grey area indicates the dip range for classical thrust ramps within the sand used in this study. The surface dip of the main thrust zone is respectively lower or higher than these classical values in models with a low or high ratio $\mathrm{R}$ and the structure hanging wall is uplifted accordingly. 
Fig. 17: Evolution of the shear stress product $\tau b . \tau d$ and shear stress ratio $\tau b / \tau d$ at the beginning of the experiments according to their prekinematic sand thickness $\mathrm{Tb}$ and silicone thickness $\mathrm{Td}$. The product $\tau b . \tau d$ increases with $\mathrm{Tb}$ and decreases with $\mathrm{Td}$, whereas the ratio $\tau \mathrm{b} / \tau \mathrm{d}$ increases with both $\mathrm{Tb}$ and $\mathrm{Td}$. On this graph, black squares represent the models performed in this study, while the pairs of numbers indicate their prekinematic brittle and ductile thicknesses $\mathrm{Tb}$ and $\mathrm{Td}$.

Fig. 18: (A) Maximum surface dip of the main thrust zone $\alpha_{\max }$, and (B) ratio $R_{\max }$ for which this maximum surface dip is reached according to the prekinematic rheological profile of the models. The pairs of numbers indicate their prekinematic brittle and ductile thicknesses $\mathrm{Tb}$ and $\mathrm{Td}$. The dashed lines correspond to the mean values of the measurement clusters.

Table 1: Scaling parameters of the models. $\mathrm{L}, \rho, \mu, \mathrm{V}_{\text {short }}, \mathrm{t}$, and $\sigma$ are respectively the length, density, viscosity, shortening rate, time and stress in nature and in the experiments. Note that the ratio between the strength and gravitational forces $(\sigma / \rho g L)$ is the same in the models and their natural prototypes, while the ratio between the inertial and gravitational forces $\left(\mathrm{V}_{\text {short }} / \mathrm{gt}\right)$ is negligible in both systems.

\section{Online depository data}

Table 2: Model parameters. In yellow, the model parameters varied for this study with the ratio $\mathrm{R}$ based on the sedimentation rate at the front of the main thrust zone. In blue, the brittle-ductile models with the highest surface dips of the main thrust zone for each prekinematic rheological profile. 


\begin{tabular}{|cccccccccc|}
\hline & $\begin{array}{c}\mathbf{L} \\
(\mathbf{m})\end{array}$ & $\begin{array}{c}\mathbf{g} \\
\left(\mathbf{m} / \mathbf{s}^{2}\right)\end{array}$ & $\begin{array}{c}\boldsymbol{\rho} \\
\left(\mathbf{k g} / \mathbf{m}^{\mathbf{3}}\right)\end{array}$ & $\begin{array}{c}\boldsymbol{\mu} \\
(\mathbf{P a . s})\end{array}$ & $\begin{array}{c}\mathbf{V}_{\text {short }} \\
(\mathbf{m} / \mathbf{s})\end{array}$ & $\begin{array}{c}\mathbf{t} \\
(\mathbf{s})\end{array}$ & $\begin{array}{c}\boldsymbol{\sigma} \\
\mathbf{( P a})\end{array}$ & $\boldsymbol{\sigma} / \mathbf{\rho g L}$ & $\mathbf{V}_{\text {short }} / \mathbf{g t}$ \\
\hline Nature & $\begin{array}{c}1000 \\
(1 \mathrm{~km})\end{array}$ & 9.81 & 2300 & $10^{19}$ & $\begin{array}{c}\sim 10^{-10} \\
(\sim 3 \mathrm{~mm} / \mathrm{y})\end{array}$ & $\begin{array}{c}\sim 5 \times 10^{13} \\
(\sim 1.5 \mathrm{My})\end{array}$ & $2.25 \times 10^{7}$ & 1 & $10^{-23}$ \\
\hline Model & 0.01 & 9.81 & 1400 & $10^{4}$ & $\begin{array}{c}7 \times 10^{-6} \\
(2.5 \mathrm{~cm} / \mathrm{h})\end{array}$ & $\begin{array}{c}7.2 \times 10^{3} \\
(2 \mathrm{~h})\end{array}$ & $1.4 \times 10^{2}$ & 1 & $10^{-11}$ \\
\hline $\begin{array}{c}\text { Model/Nature } \\
\text { ratio }\end{array}$ & $10^{-5}$ & 1 & 0.6 & $10^{-15}$ & $6 \times 10^{4}$ & $1.7 \times 10^{-10}$ & $0.6 \times 10^{-5}$ & Identical & $\begin{array}{c}\text { Equally } \\
\text { negligible }\end{array}$ \\
\hline
\end{tabular}

Tab. 1 


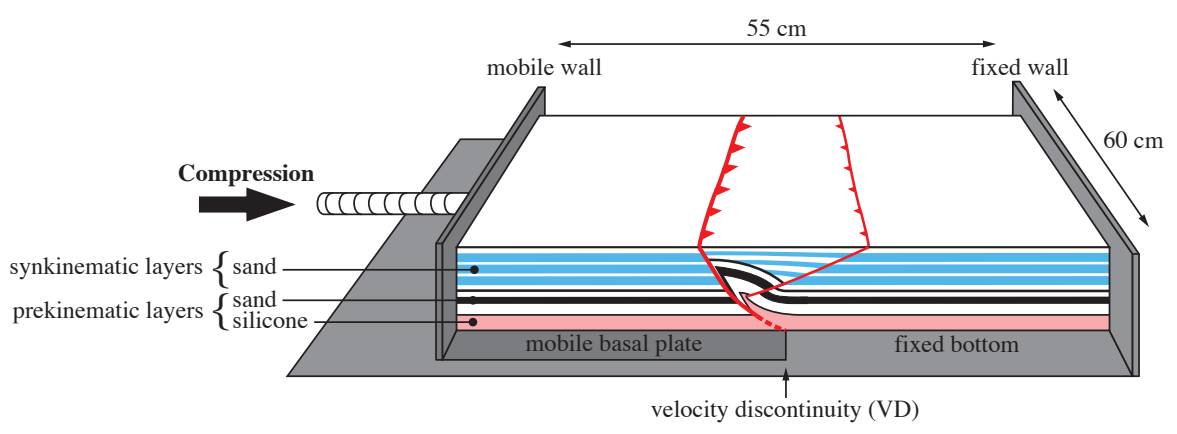

Fig. 1 


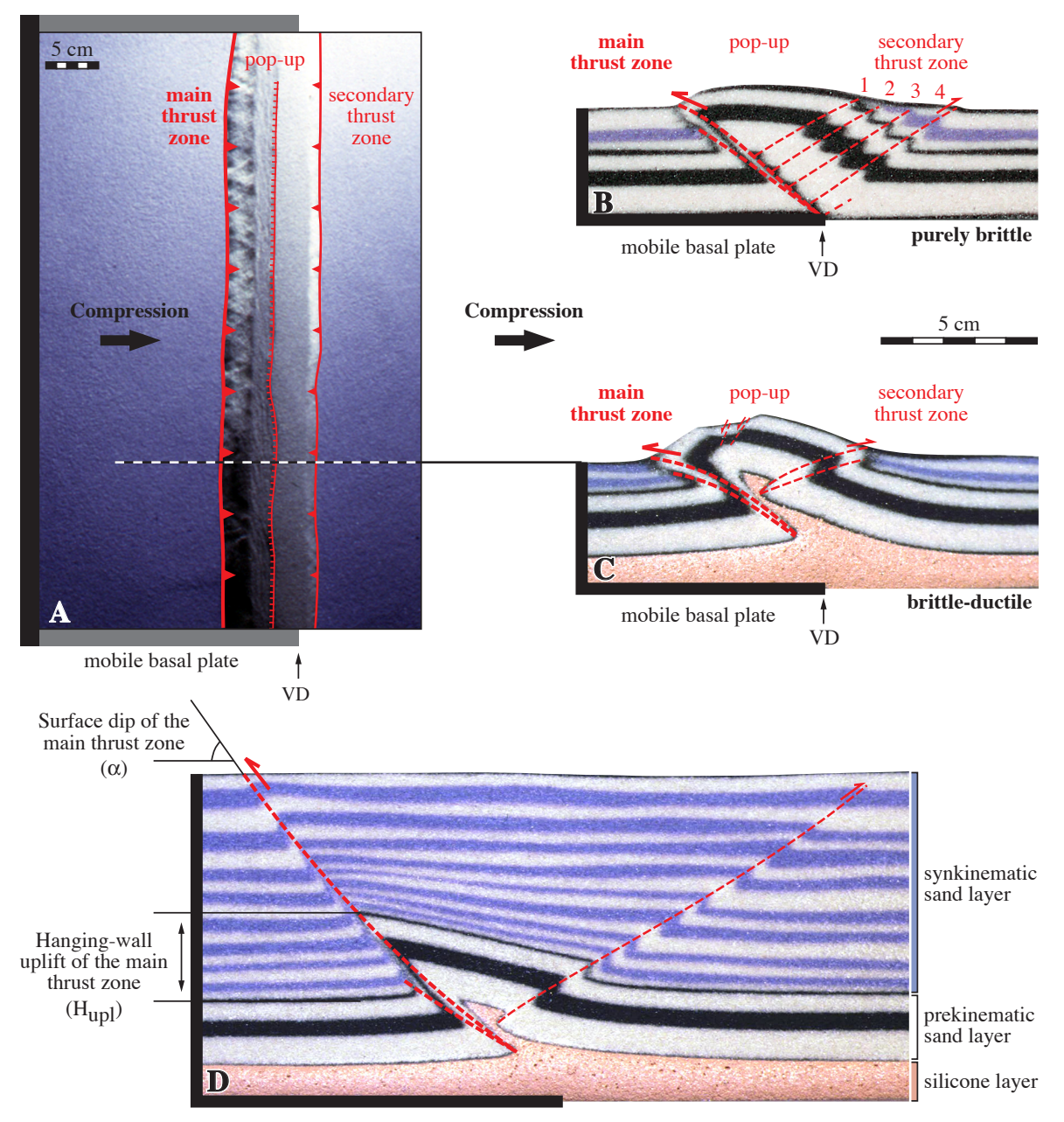

Fig. 2 


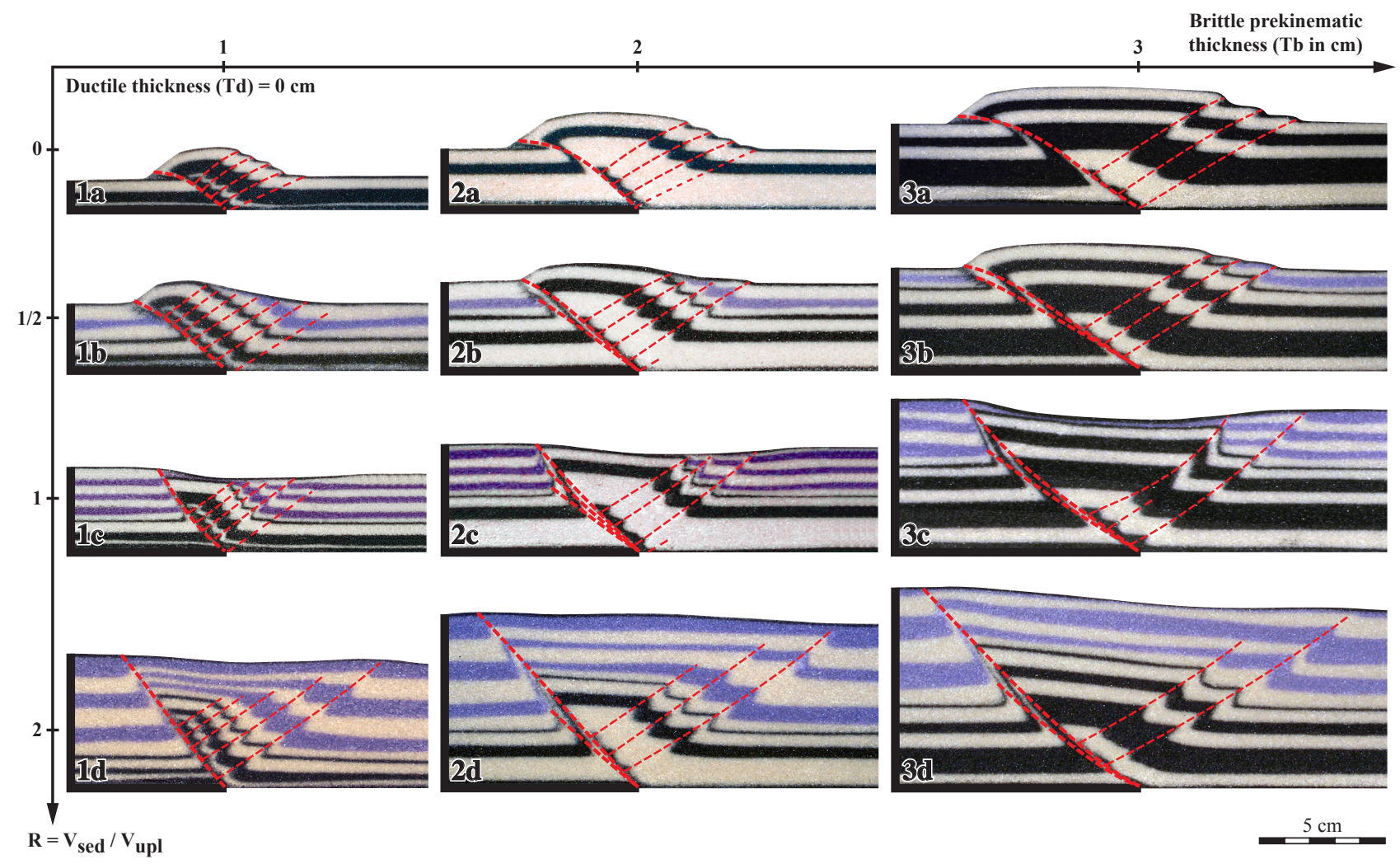

Fig. 3 


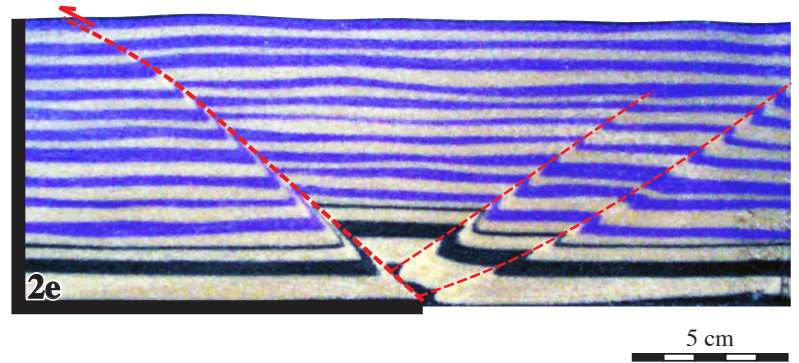

Fig. 4 

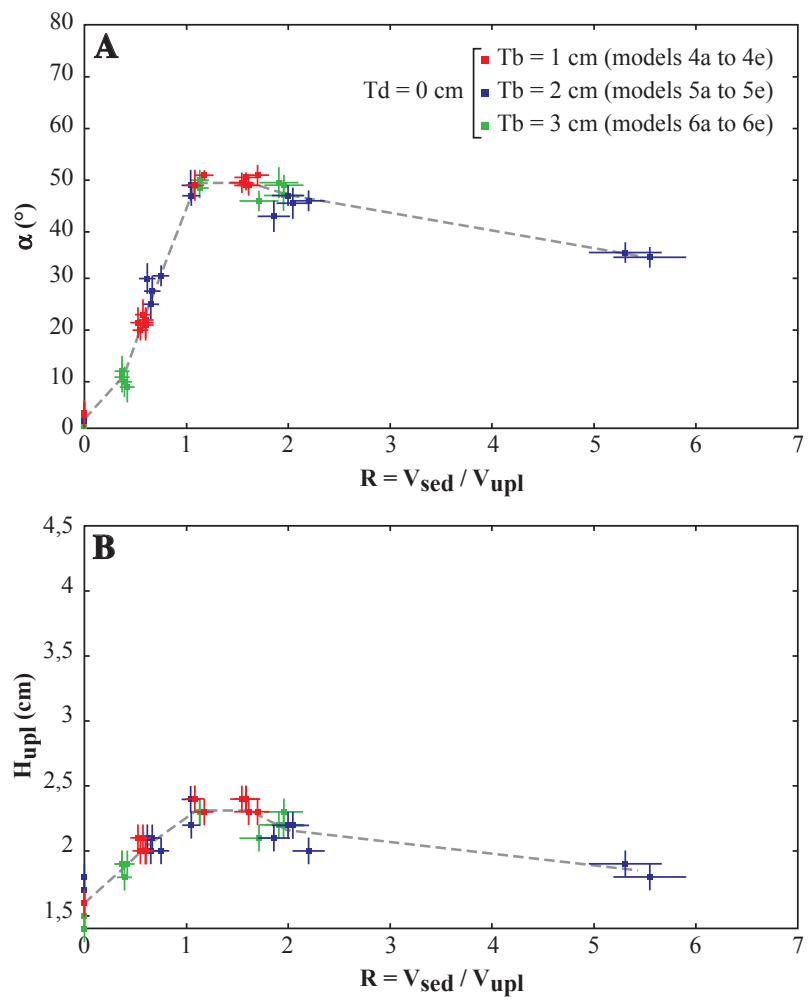

Fig. 5 


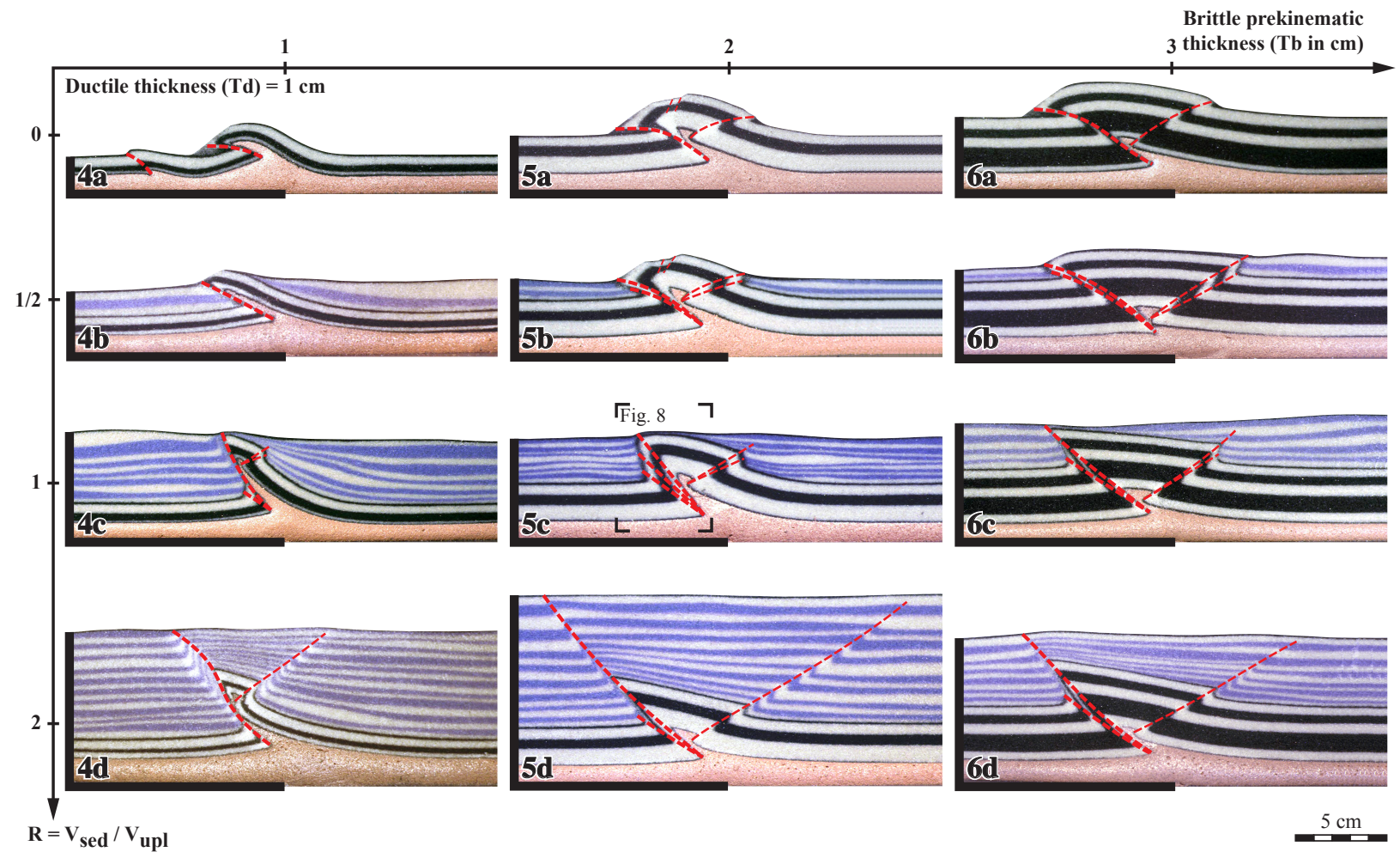

Fig. 6 


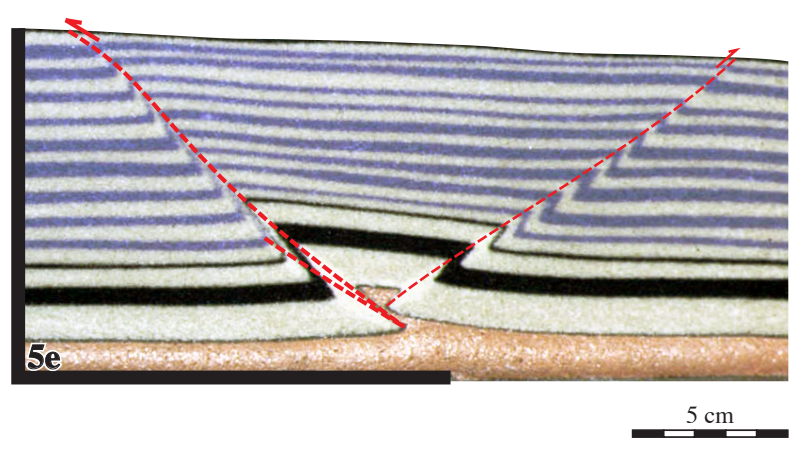

Fig. 7 


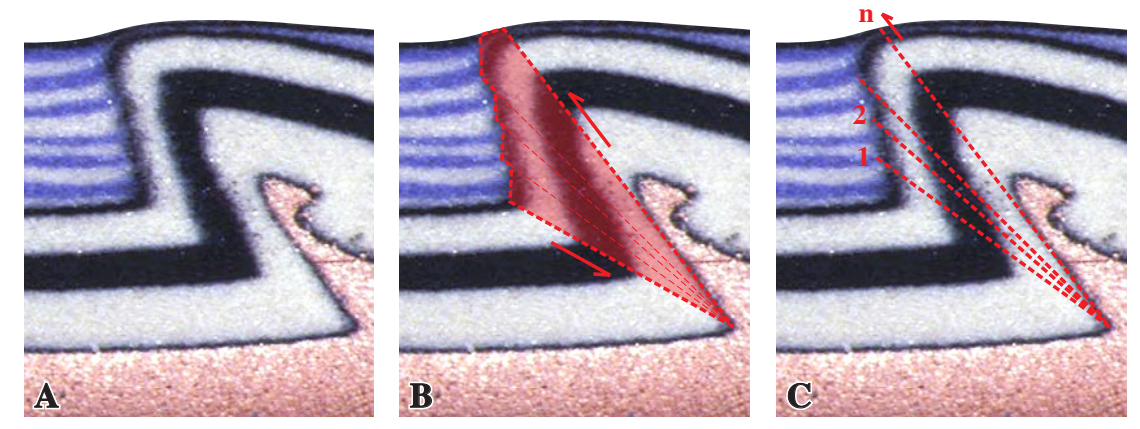

Fig. 8 

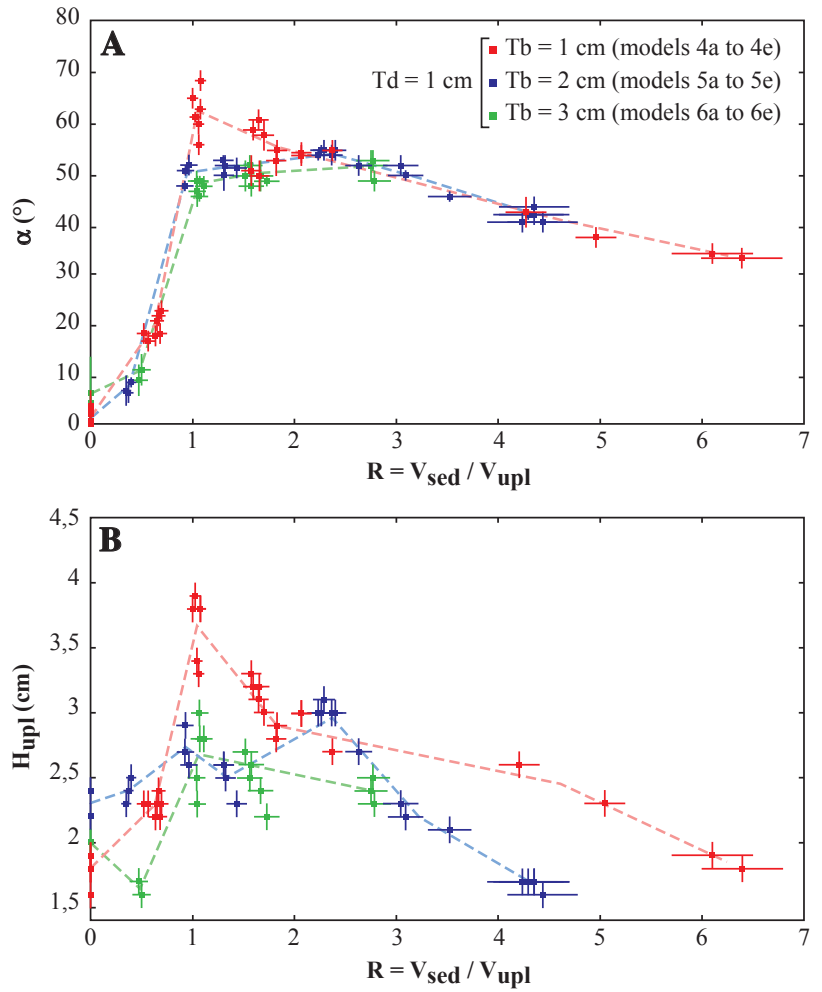

Fig. 9 


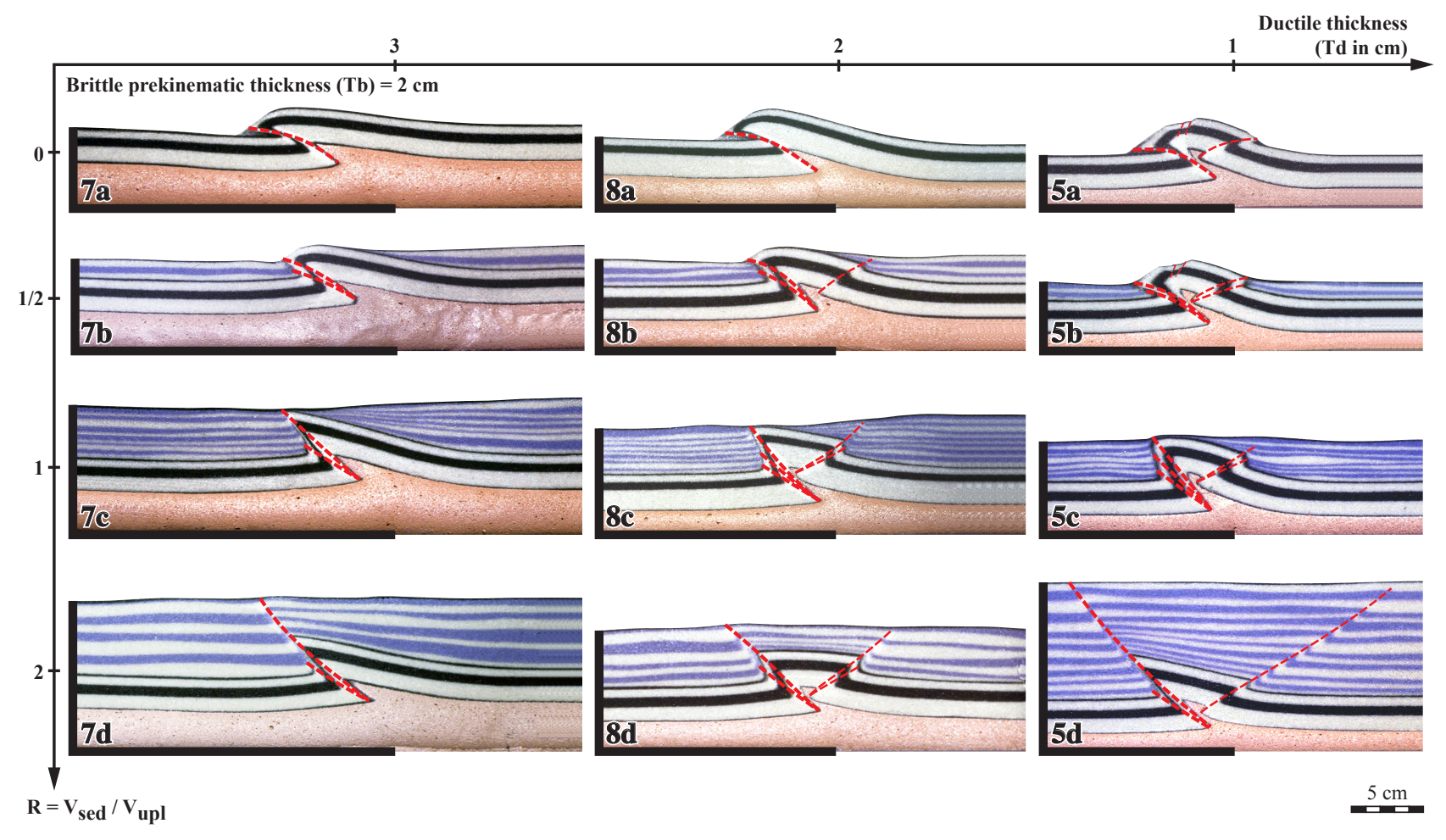

Fig. 10 

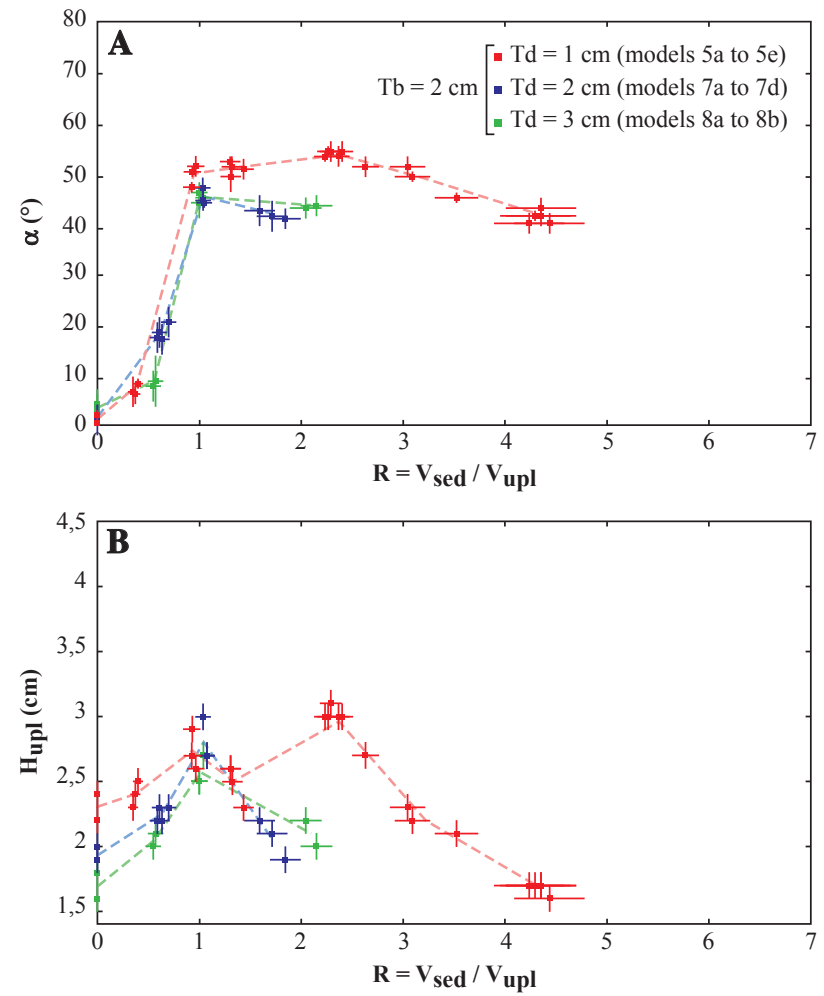

Fig. 11 

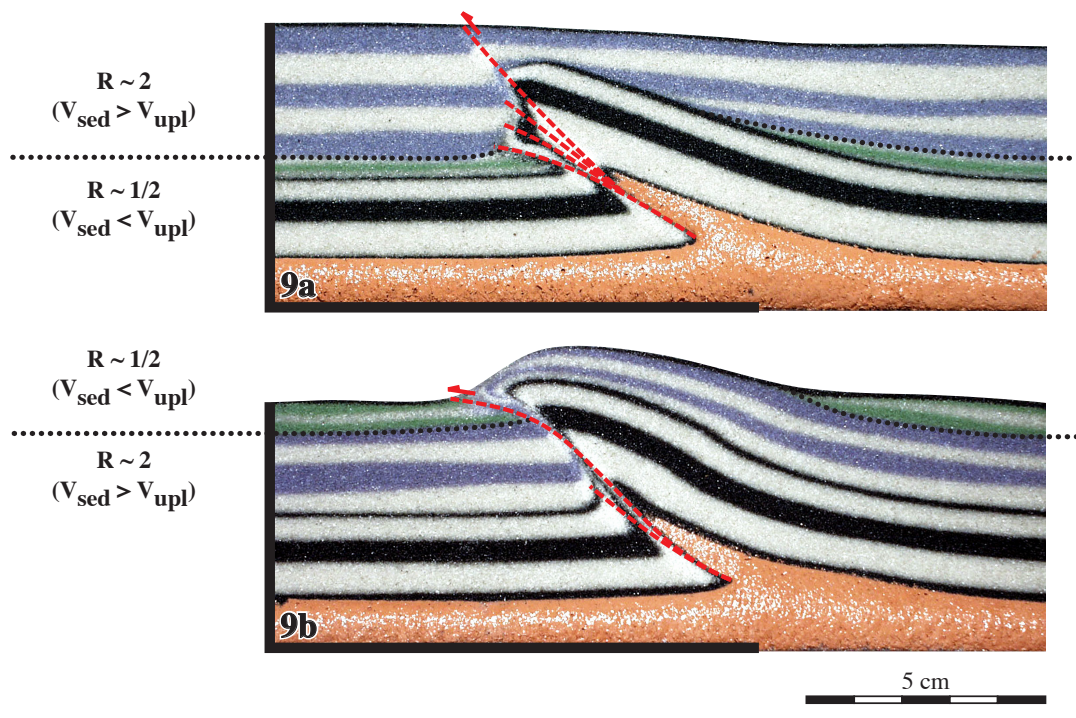

Fig. 12 


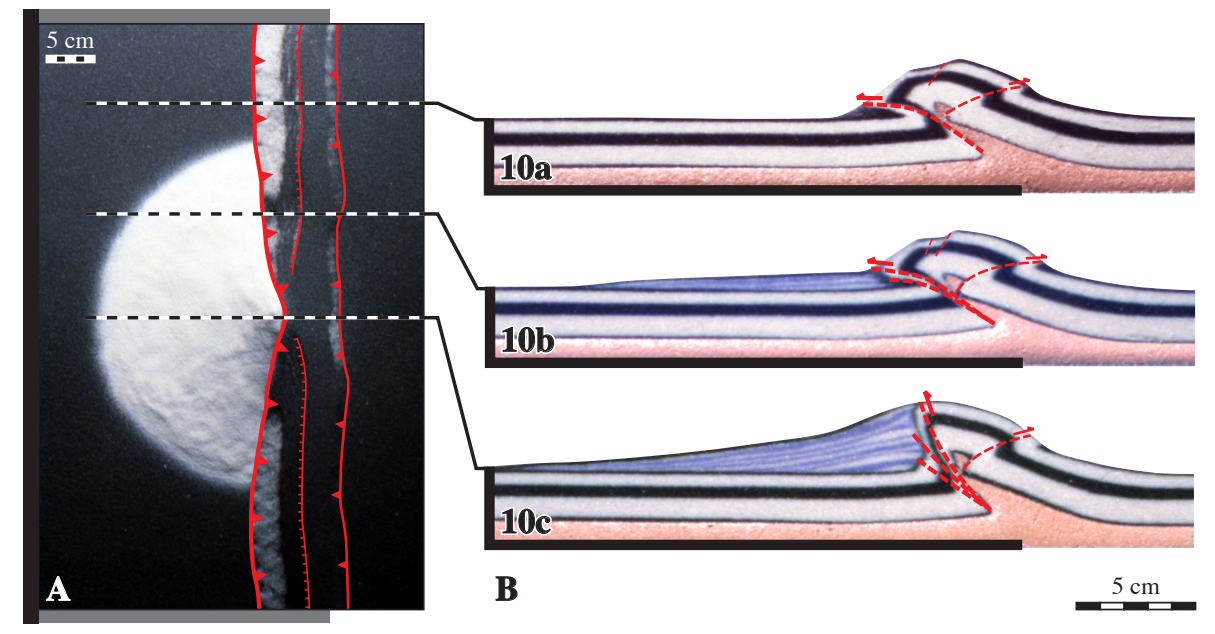

Fig. 13 


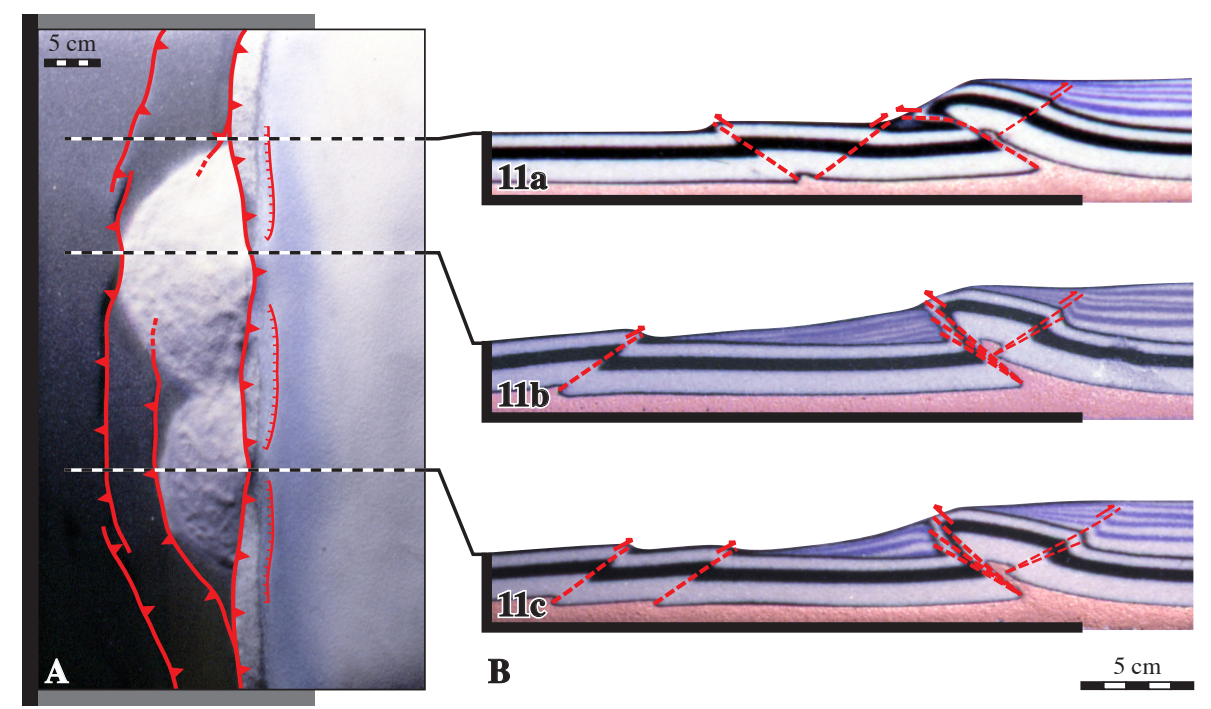

Fig. 14 


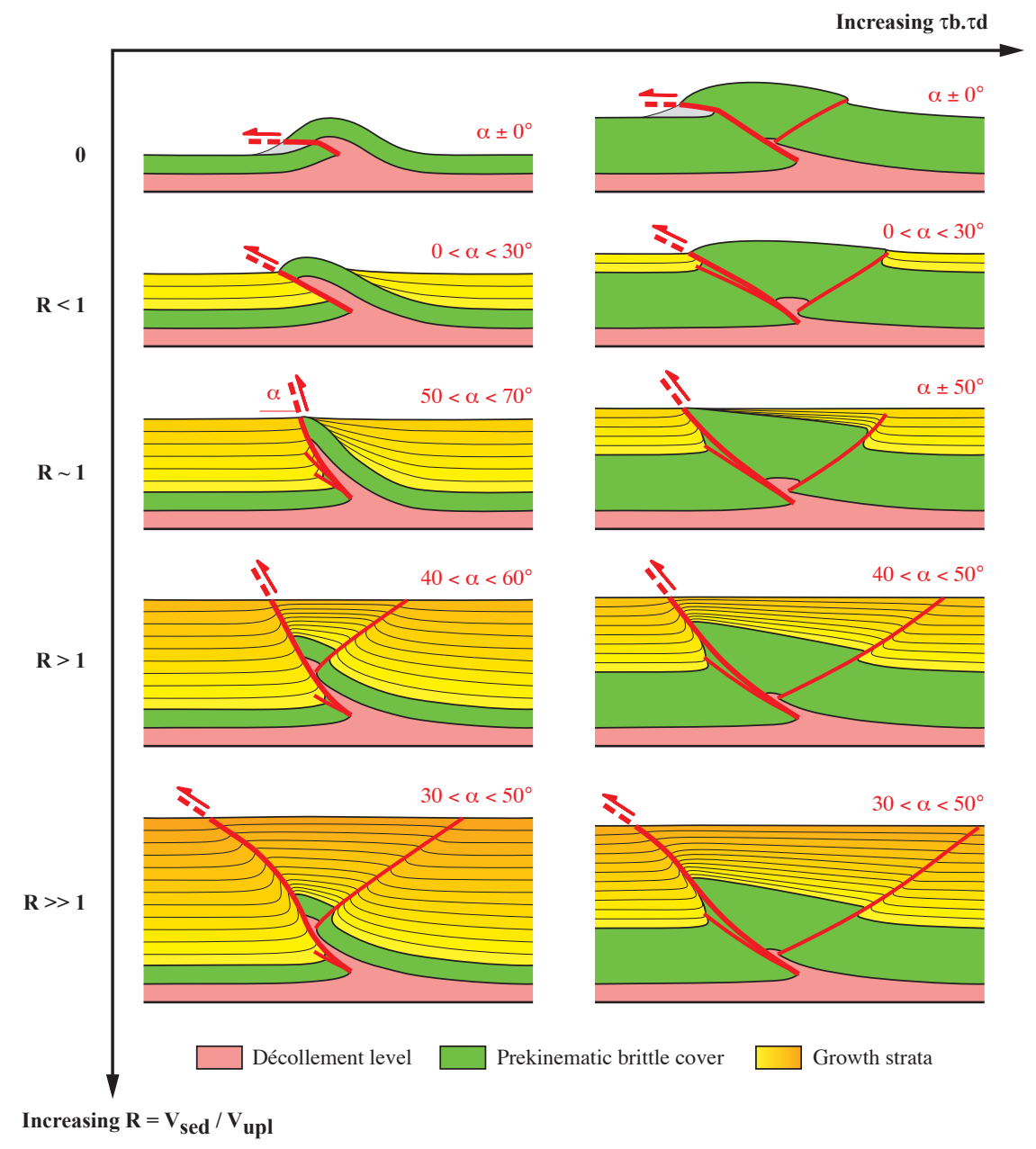

Fig. 15 


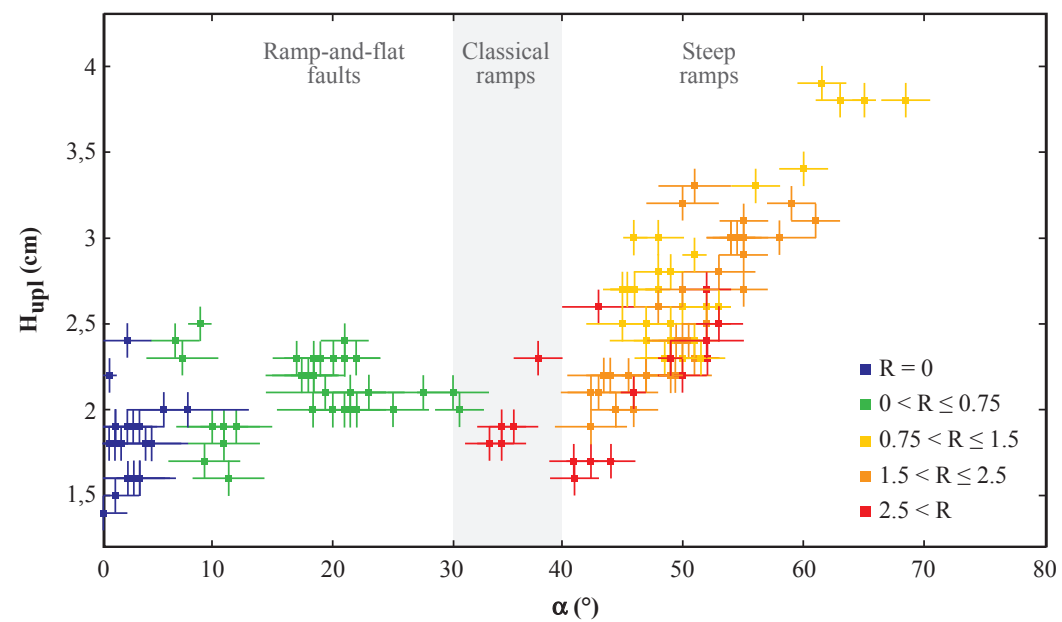

Fig. 16 


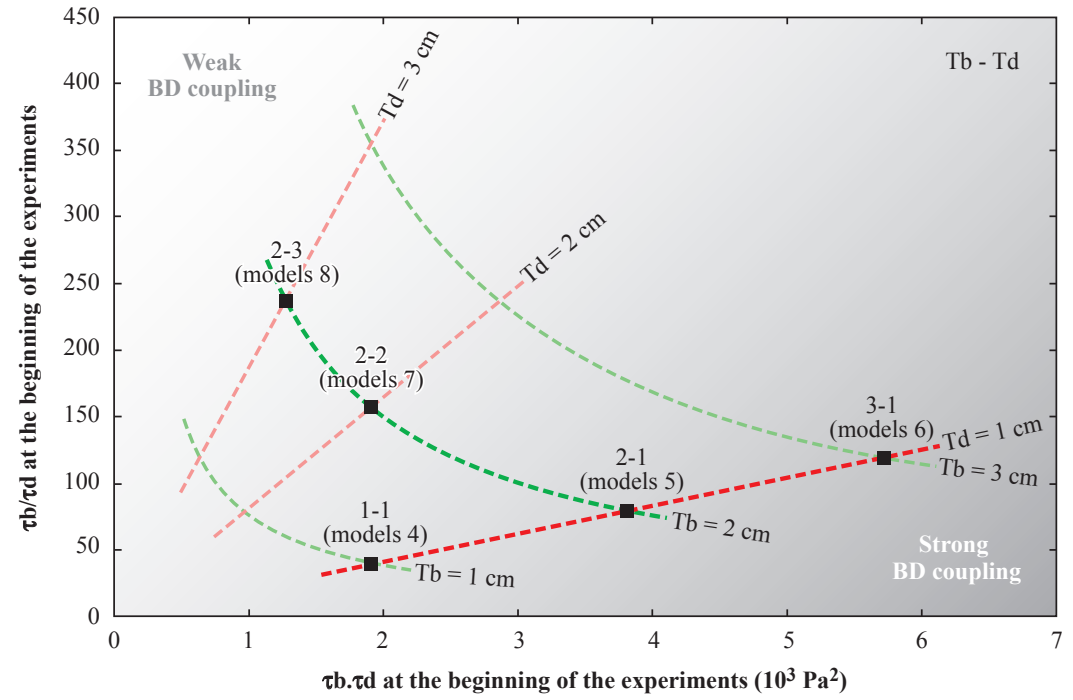

Fig. 17 

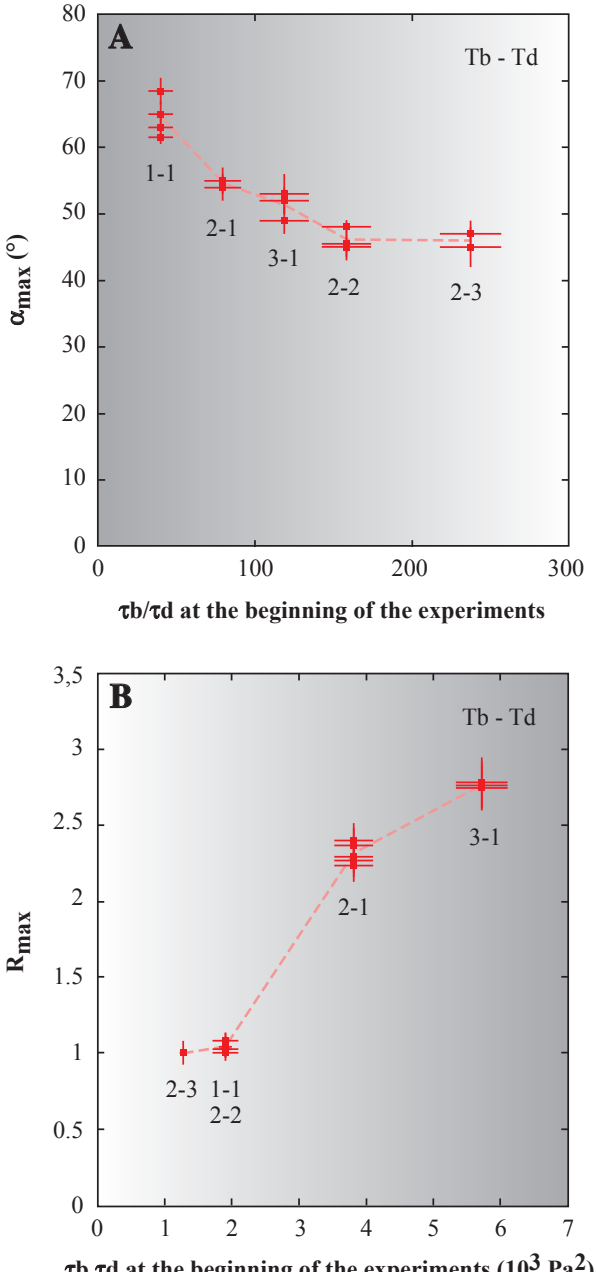

Fig. 18 